\title{
تحليل الأخطاء الإملائية في تدريس الكتابة لطلاب الصف الثاني من مدرسة "المرضية" المتوسطة الإسلامية تجنجسير لألائلة الهؤ وارو باميكاسن.
}

\author{
Umar Bukhory \\ (STAIN Pamekasan/ email: bukhory06@gmail.com) \\ Sufiyeh
}

(SD Plus Nurul Hikmah Pamekasan)

\begin{abstract}
Abstrak:
يتضمن هذا البحث المتعلقة بالأخطاء الإملائية على المسألتين هما: ما

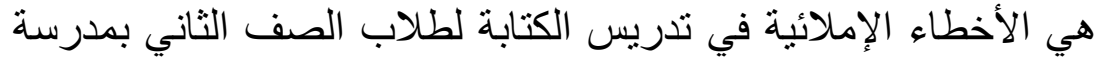

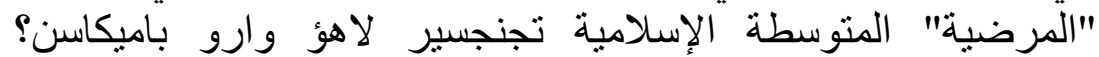

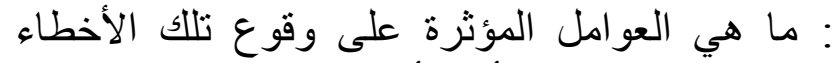

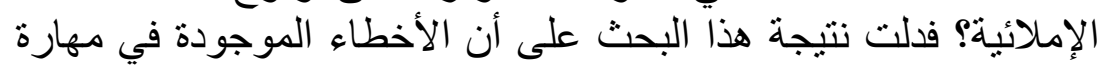

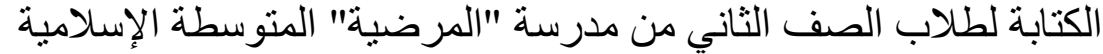
تجنجسير لاهؤ وارو باميكاسن هي الأخطاء المشنملة على الأنس الناحيتين:

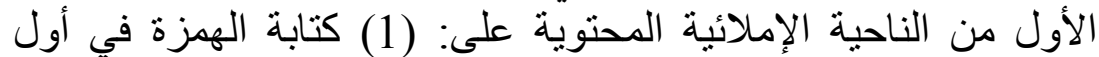
الكلمة أو في وسطها أو في آخرها، (2) كتابة التاء المربوطة التهاء أو التاء

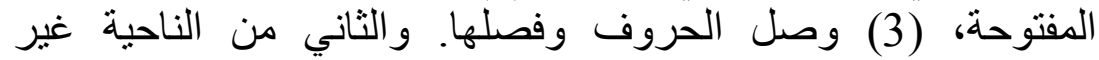
الإملائية المحتوية على: (1) الكتابة بإبدال الحروف، (2) (2) الكتابة بزيادة التهاة

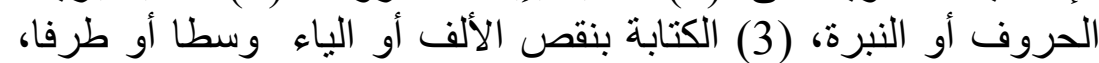

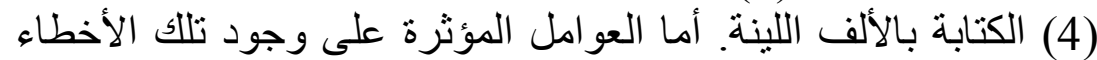

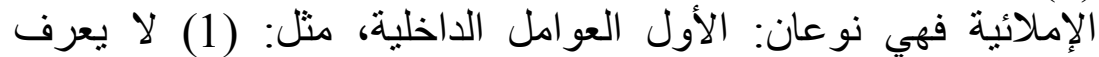

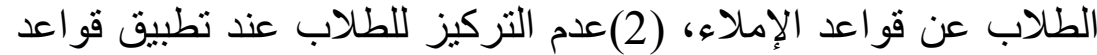

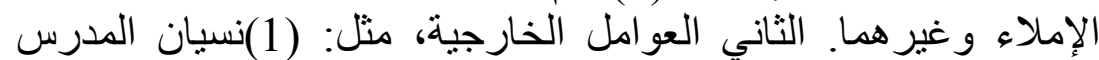
قو اعد الإملاء، (2) ندرة الممارسة في كتابة الإملاء على الطلاب من الندان

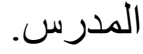

Kata Kunci:

Error Analysis, al-Akhthâ' al-Imlâiyyah, Tadrîs al-Kitâbah al-'Arabiyyah

حوادث ووقائع. 1 وتظهر أهمية الكتابة

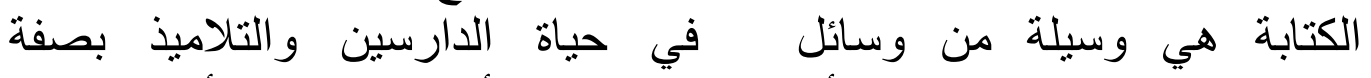

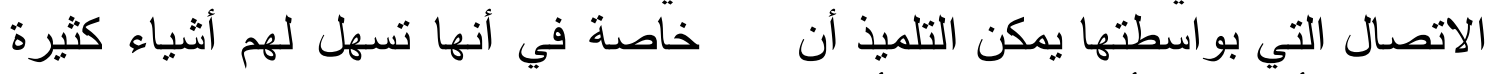

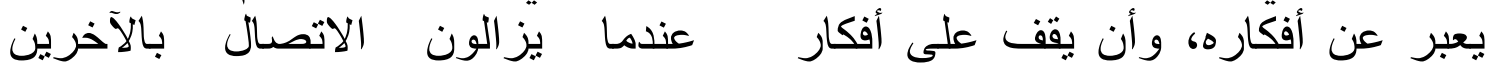
1محمود رشدي خاطر و وأصدقائه.

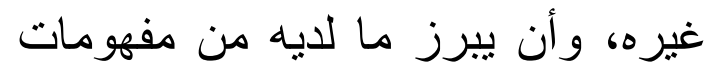
طرق تدريس اللغة العربية والتربية الدينية:

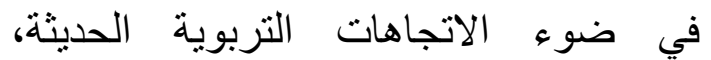

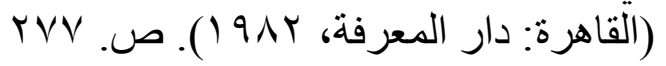


كتابته سليمة و اضطحة فإننا نعينه علي على أن تكون ولمعرفة قوانين الكتابة، نبحث

عن الإملاء الذي هو إحدى فروع اللغنة

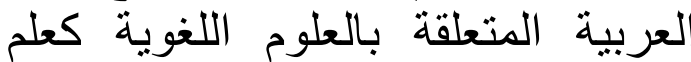

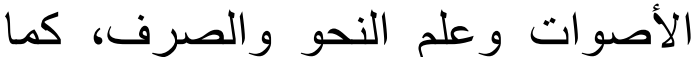
أنها تتعلق بإحدى مهار ات اتل اللغة، وهي التي

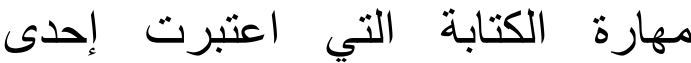
المهارات اللغوية الإيجابية المبتكرة التهاتية

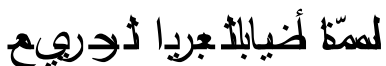

جميع ألوانه و أنشطته. ${ }^{4}$ ولكونه قوانينا

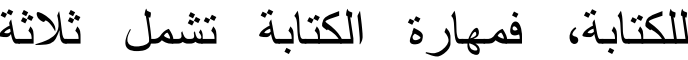
أقسام، فهي: أولا، مهارة التهجي بطريقة

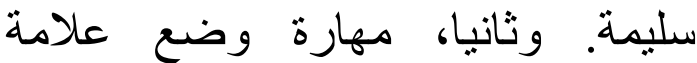
الترقيم في مواضعها. و ثنالثا، مهارة

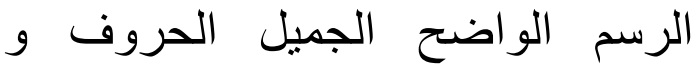
الكلمة. ومهارة التهجي بطريقة سليمة التئي تشتمل على الثيئين :الأول القدرة على القى نطق الأحرف الهجائية في الكلمات الفئ بنطق صحيح. و الثاني، القدرة على كتابة الأحرف الهجائية بكتابة صحيحة. 5 الإملاء هو تحويل الأصوات لهنات المسموعة المفهومة إلى رموز مكتوبة التهوبة

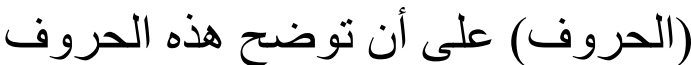
في مواقعها الصحيحة من الكلمة وذلك الك الك لاستقامة اللفظ وظهور المعنى المر اد. وكثير ا ما يكون الخطأ الكتابي في الإني الإملاء، أو في عرض الفكرة سببا في

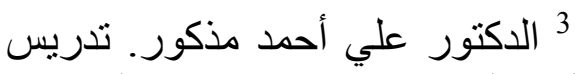

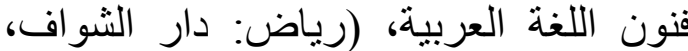

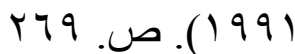

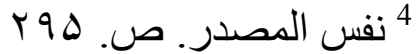
${ }^{5}$ Ma'rifatul Munjiah, Imla' Teori \& Terapan, (Malang: UIN Malang, 2009), hal. 21

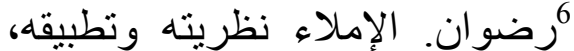
(مالانج: جامعة مو لانا مالك إبر اهيم الإسلامية
و التعبير عن أفكار هم، كما أنهم يحتاجون

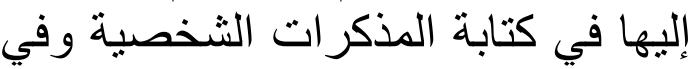

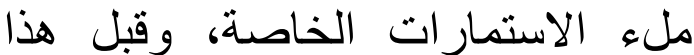
وذاك فهي وسيلة التعليم وتمكنهم من الإنية القدرة في الإجابة عن أسئلة الاختبار ات المطلوبة منهم تحريريا. وتعد مهارة الكتابة من المهار ات ات التهاب

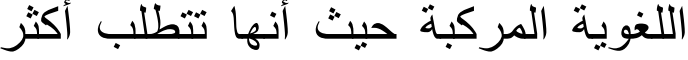
من حاسة للعمل فيها، فاليد تخط، و العين تتابع، والعقل براقب وينظم. ومن أجل فيل هذا التعقيد و التركيب، أتى تعليم الكتابة

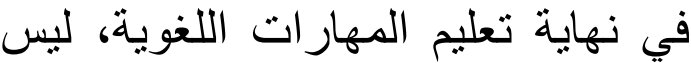

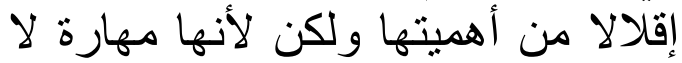

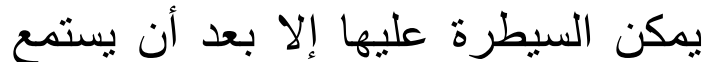

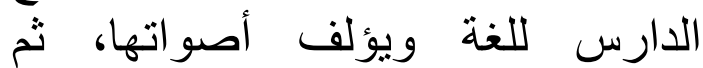
يحاكيها نطقا وحديثا ثم يعرف رموز التها في القر اعة و أخير ا يكتبها. يتفق اللغويون و التربويون

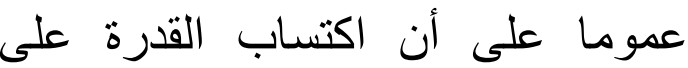
التعبير الواضح الجميل هو الحصيلة النهائية لتعليم اللغة العربية، أبي أنه هو النها الهدف النهائي الثامل لتعليم اللغة. فكل التهل

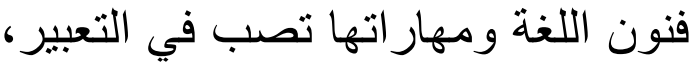

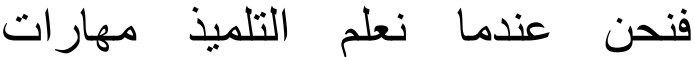
الاستماع الجيد، فإننا نقصد بذلك تقوية قدرته على التفكير والتعبير والاتصال.

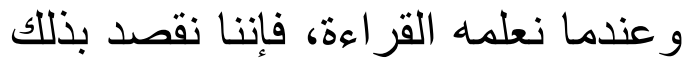

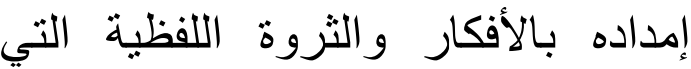

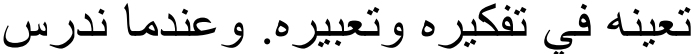
له الأدب، فإنتا نمده بالأفكار الجميلة

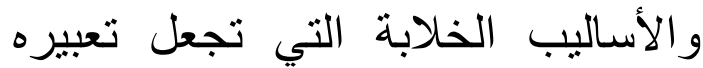
مثيرا وجذابا وموحيا. و عندما نعلمه لتهيله

الدكتور : عبد الحميد عبد الله الهيد وأصدقائه. أسس إعداد الكتب التعليمية لغير

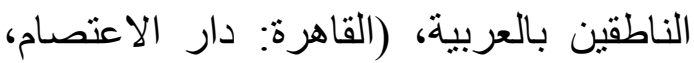


شركة أو معمل أو متجر أو مصلحة من

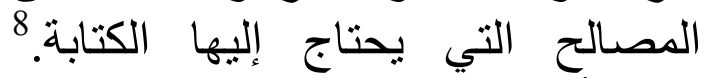

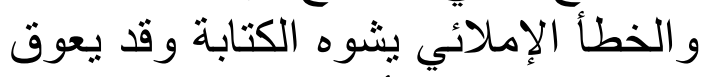

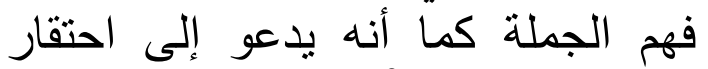
الكاتب وازدر ائه. 9

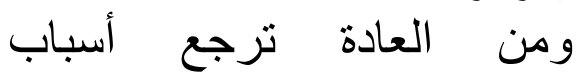

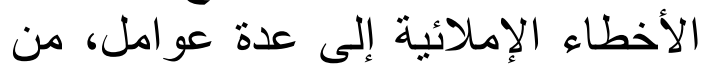

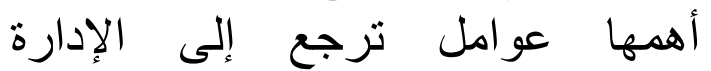

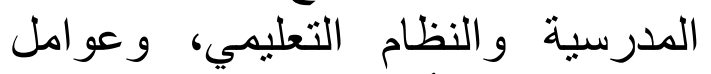

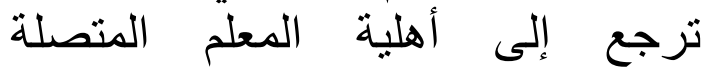

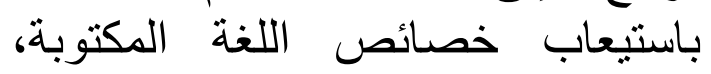

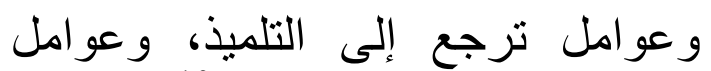

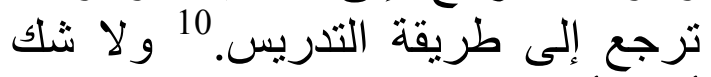
أن الأخطاء الإملائية لايتعلق بالذئن

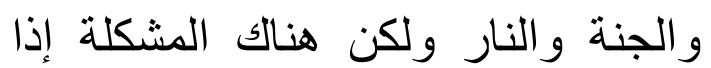
نشأ ذلك من الطلاب و والأساتيذ و غير هما لأنهم يستغرقون أوقاتهم في تعليم اللغة الأنة

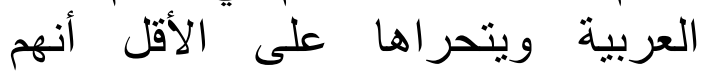
يقرؤون ويكتبون النص العربي في الافي

أجري هذا البحث العلمي فى العي حياتهم. مدرسة "المرضية" المتوسطة الإسلامية تجنجسير لاهؤ وارو باميكاسن وكانت الإنية من إحدى المدارس الإسلامية التئي تدرس فيها اللغة العربية. رأى الباحث

8حمود رشدي خاطر و أصدقائه.

طرق تدريس اللغة العربية و التربية الدينية:

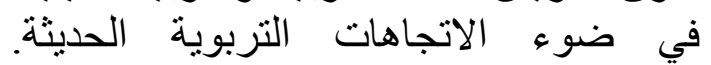

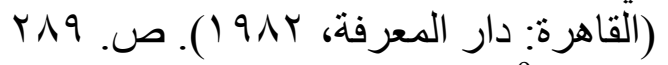

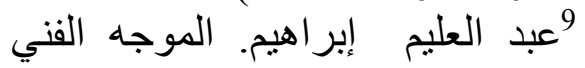

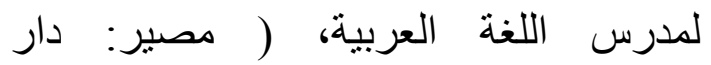

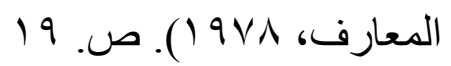

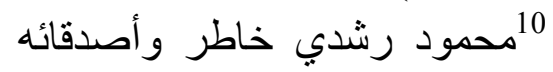

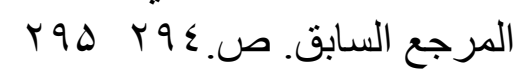

${ }^{11}$ Abdul Mukti Thabrani, Kaidah-Kaidah Dasar Penulisan Bahasa Arab, (Pamekasan: Elmona Center, 2011), Hal. 1-2.
قلب المعنى، و عدم وضوح الفكرة، ومن

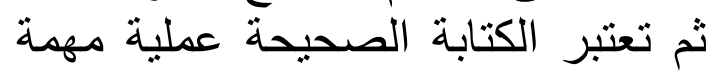
في التعليم على اعتبار عنصر أساسي التئي

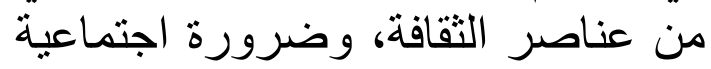

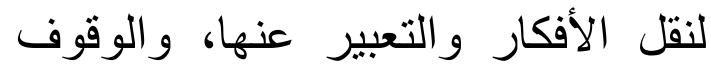
على أفكار الغير و الإلمام بها. وتدريب التناميذ على الكتابة في لئي إطار العمل المدرسي، يتركز في العناية بأمور ثناثنة: قدرة التنلاميذ على المئي الكتابة العناية

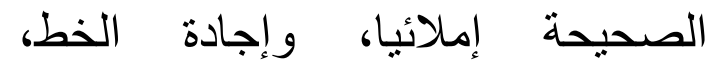

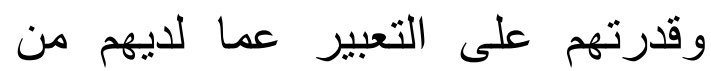

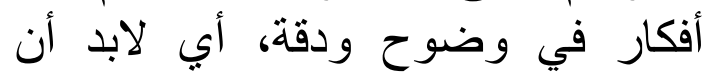

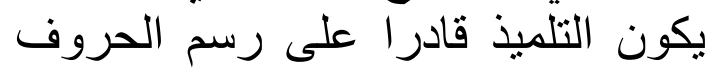

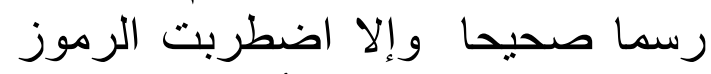

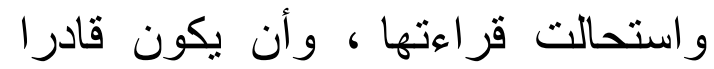

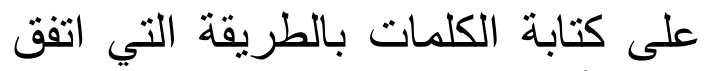

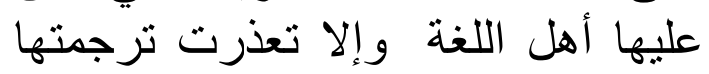

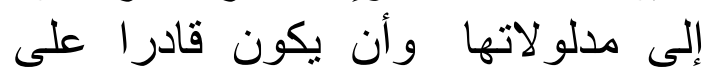

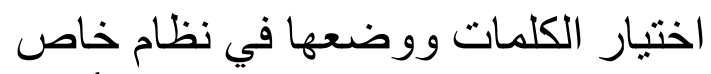
وإلا استحال فهم المعاني وضعان والأفكار المشتملة عليها . الإملاء فرع مهح من فروع اللغة

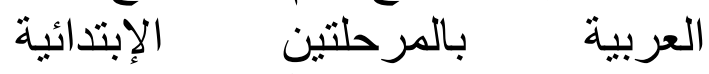
والإعدادية، وهو من الأسس المهمة في الإنية التعبير الكتابي. و إذا كانت قواعن الاعد النحو النهو

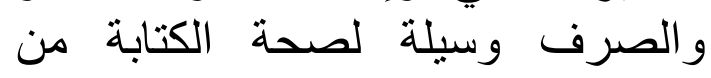
الناحية الإعرابية، فإن قواعد الإملاء تحل فى نفس المستوى من الإنة حيث الصورة الخطية. و الخطأ الإملائي يشوه

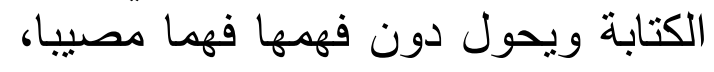

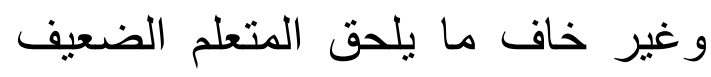
في الهجاء من ضرور في حياته العملية،

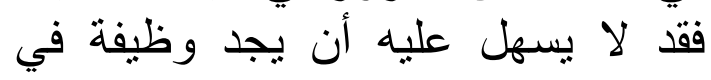

7الدكتور حسن شحاتة. تعليم اللغة

العربية بين النظرية و التطبيق، القية (القاهرة:

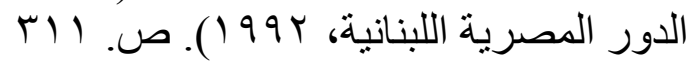


مدرسة "المرضية" المتوسطة الإسلامية تجنجسير لاهؤ وارو باميكاسن؟

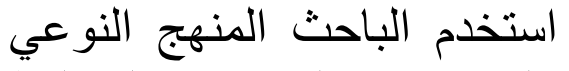

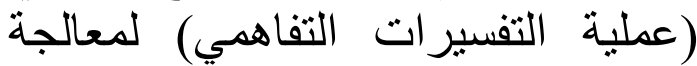
المسئلتين المذكورتين مع إجر اء الدراسة التها الوصفية عنهما. ورأى دون الأرين الأري

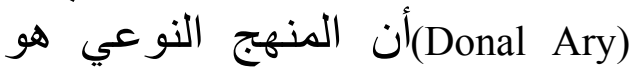
البحث عن المظهر المخصص لانه النة

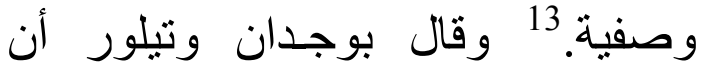

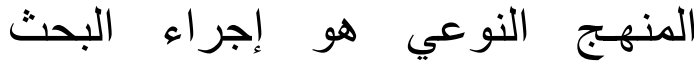

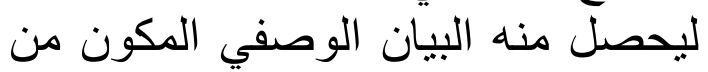
الكلام المكتوب و الظو اهـر التي تحصل التهن عليها الملاحظة. تعني أن النها البيانات وتحليلها ونتائج التحليل وصفا لثنيل الثكل هذه الظو اهر. 14

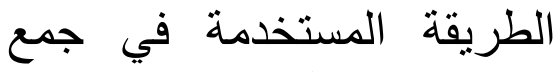

البيانات هي: الملاحظة غير المشاركة

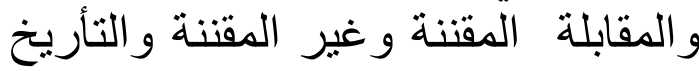
و الوثائق. وتجري عملية عرض البنائن والبيانات فيها من تاريخ 16 ديسمبير 2013 إلى منى 24 مارس 2014، و وأما منهج تحليل البيانات المستخدم فيه هو فئل تحليل الأخطاء.

وتستخدم الملاحظة غير

المشاركة لنيل البيانات عن تطبيق تُبن مدرسي اللغة العربية تدريس مهارة

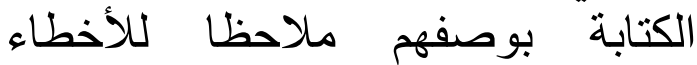

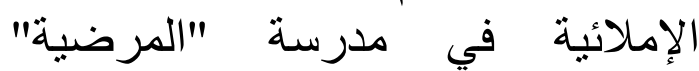

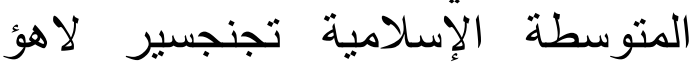
وارو باميكاسن، مع أحوال طلاب لاهن

${ }^{13}$ Donald Ary et.al, Introduction to Research in Education, (New York: Rinehart Winston 1979), p.29.

${ }^{14}$ Lexy J. Moleong, Metodologi Penelitian Kualitatif, (Bandung: PT. Remaja Rosdakarya, 2007), hal. 3.
في مرحلة الملاحظة قبل إجراء البحث أن يشعر بعض طلابها وجود الأنها ألخطاء الإملائية عند تعلم اللغة العربية.

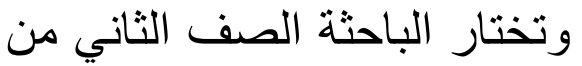
مدرسة "المرضية" المنوسطة الإسلامية الئة تجنجسير لاهؤ وارو باميكاسن، لأنه الأنه

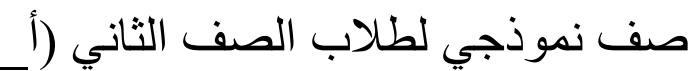

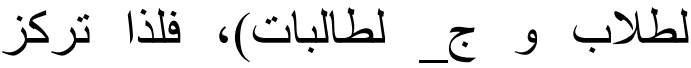

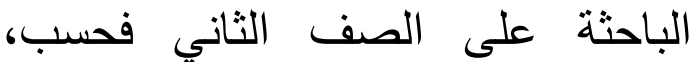
تسهيلا في كتابة هذا البحث. بوجود ذلك فتريد البانية الباحثة أن تحلل الأخطاء الكتابية باستخدام تحليل الأخطاء تعني الأخطاء الإملائية التي فئي

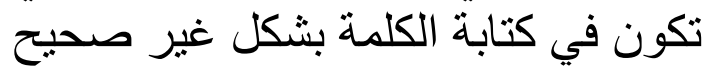

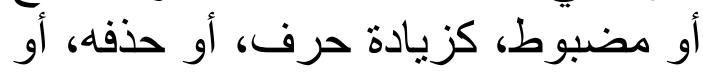

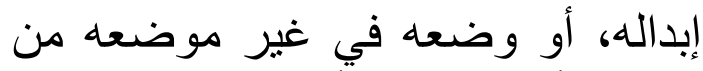
الكلمة. أما تحليل الأخطاء فهو التيل فوضليل التيل الذي يبين عن أخطاء لغة الداء الإسين في اللغة الأجنبية. 12 فلذا تريد الباحثة أن الن النين

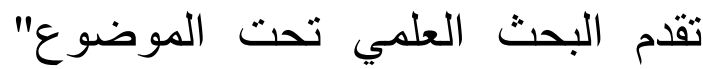

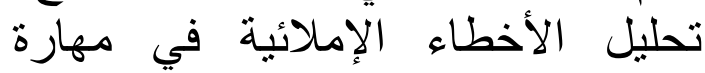
الكتابة لطلاب الصف الثاني من مدرسة فئة الأنة "المرضية" المتوسطة الميكة الإسلامية تجنجسير لاهؤ وارو باميكاسن".

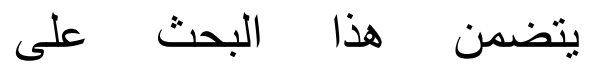
المسألتين فيه، هما: ما هي الأنين الخطاء

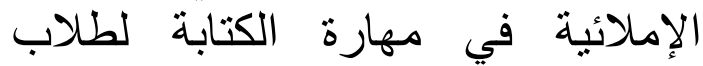
الصف الثاني من مدرسة "المرضية"

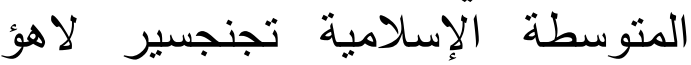

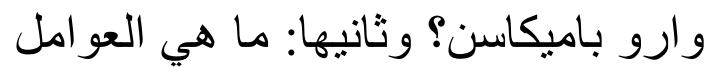

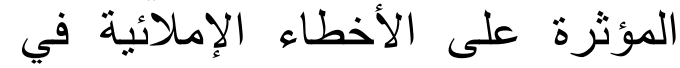
مهارة الكتابة لطلاب الصف الثاني من فن فئل

${ }^{12} \mathrm{Jos}$ Daniel Parera, Linguistic Edukasional; Metodologi Pembelajaran Bahasa Analisis Kontrastif Antar Bahasa Analisis Kesalahan Berbahasa, (Jakarta: Erlangga, 1997), hal. 140. 
الصف الثاني فيها عند تنفيذ النشاطات باميكاسن جاوى الثرقية. أصبح المرحوم كياهي الحاج مرضيا المؤسن

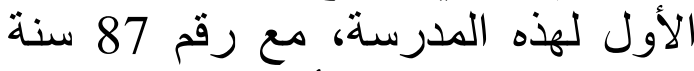
1993 كرقم شهادة التأسيس.

الأخطاء الإملائية في مهارة الكتابة لطلاب الصف الأملائة في من من مدرسة الثنية

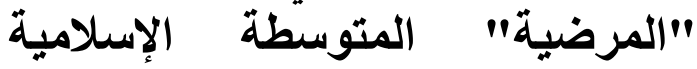
تجنجسير لاهؤ وارو باميكاسن.

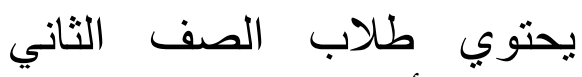
(الصف الثامن أ للبنين) الذين حضرواب الصني

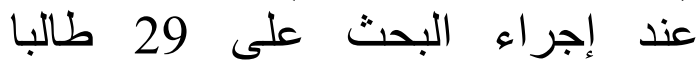
وتحتوي طالبات الصف الثاني (الصف

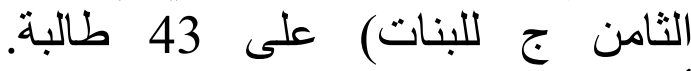

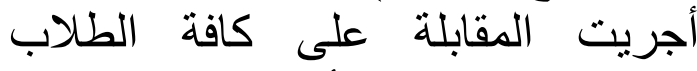
المذكورين، فاستتبط أن العو امل المؤثرة

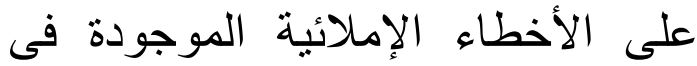

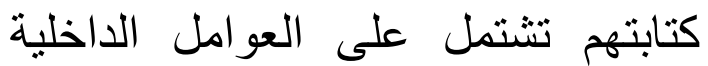
التي تعود إلى نفس الطلاب والخئ والخارجية

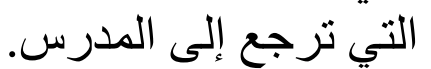

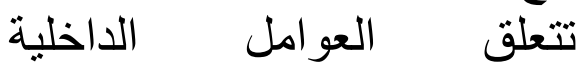
بالمشكلات اللسانيات الصغرى و الكلية.

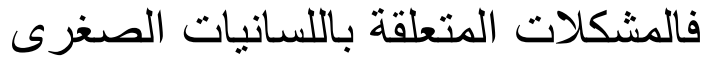

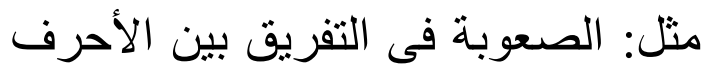

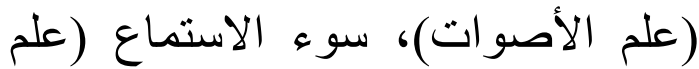
الأصوات)، وما إلى الى ذلك. أما أمثلة العوامل المتعلقة باللسانيات الكلية فمنها: العجلة فى الكتابة، عدم المعرفة الدقيقة عن كيفية وصل الحروف وكتة وكتابة الهمزة، عدم التعود في الكتابة العربية

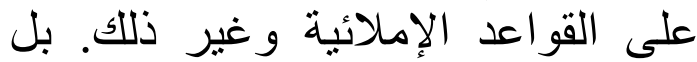
كان بعض الطلاب و الطالبات يشعرون

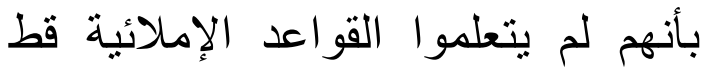
عبر سن تعلمهم. تحليل البيانات

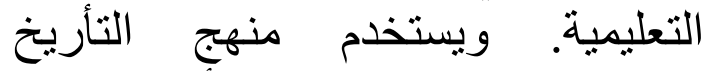
و الوثائق لنيل ما تتعلق بالأوراق التئي

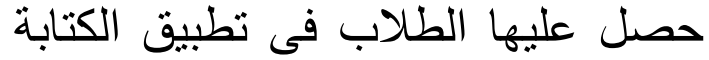
الإملائية. ومن الوثائق المحتاجة إليها

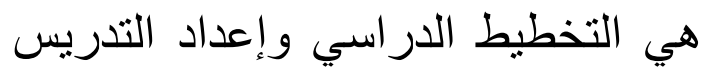
في مادة اللغة العربية وخاصة فئة فيما يتعلق الإنق بمهارة الكتابة الإملائية.

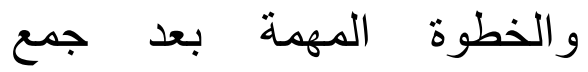

البيانات هي تحليل البيانات. وفى هذئ لئل البحث تستعمل الباحثة منهج تحليل البانيل الأخطاء. أما الخطوات في تحليلها فيما يلى: 1) جمع المادة، 2) تحديد الأخطاء، فئاء الخطاء

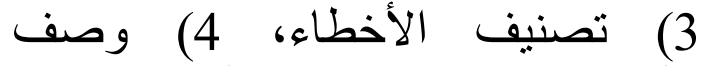

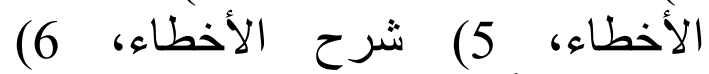
تصويب الأخطاء.

عرض البيانات وتحليلها

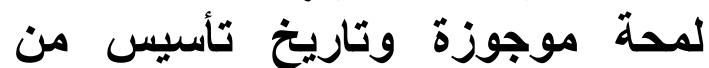

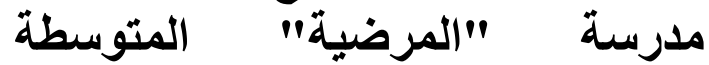

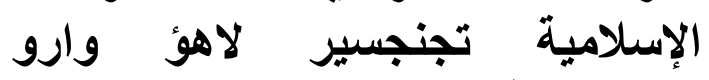
باميكاسن فهي كما يلي: سمي ميدان البحثي بمدئ بمدرسة "المرضية" المتوسطة الإسلامية تجنجسير لاهؤ وارو باميكاسن وحكي الميكية

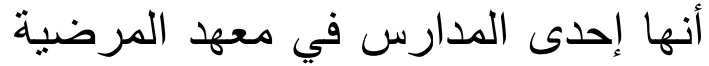
الإسلامي بجانب الهدي مدرسة لتربية الأبناء ومدرسة الثانوية ومدرسة العالية. وأما مداء

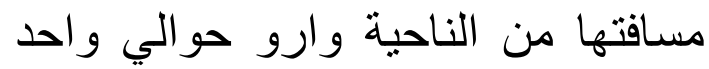

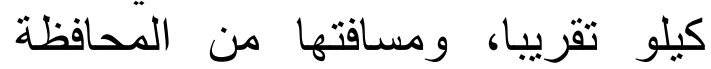
باميكاسن حوالي خمس و عشرون كيلو

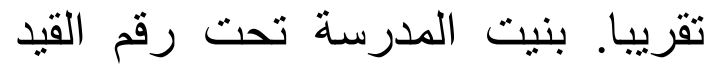
121235280107 بعد إصدار القرار

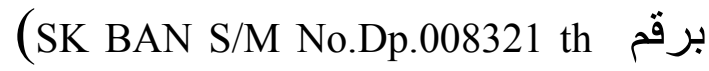

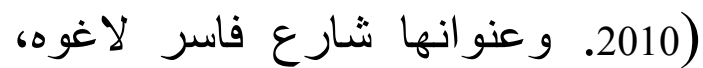
دنفتيه، قرية تجنجسير لاهؤ وارو لاعتوه 
المتوسطة الإسلامية تجنجسير لاهؤ

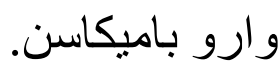

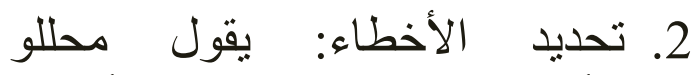
الأخطاء: إنه عملية تحديد الأخطاء

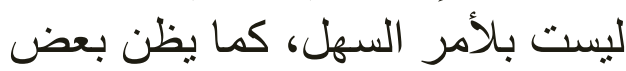

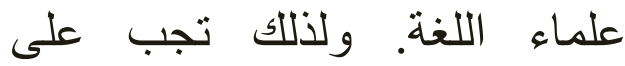
الباحثة في تحليل الأخطاء أن تكون عالمة باللغة التي تبحت فئ فيها،

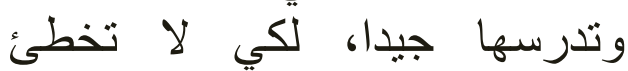

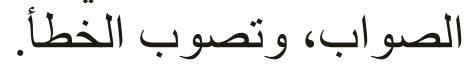

1. جمع المادة: وهذه الخطوة تتعلق بمنهجية البحث، وكيفية جمع المادة لادة

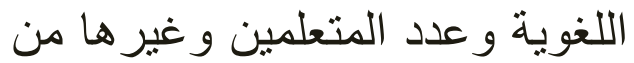
المعلومة المفيدة، ولقد جمع العلماء

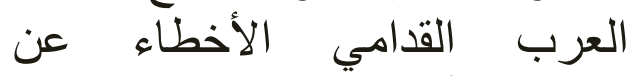
طريقين أولهما شفوي، و وثانيهما

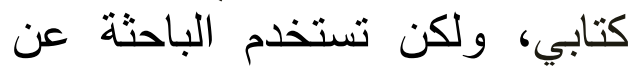
طريقة الكتابي أي الأخطاء الإملائية

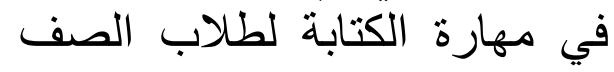

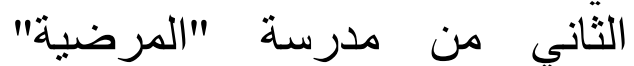
1) الأخطاء الإملائية في مهارة الكتابة لطلاب الصف الثاني (في الصف الثامن (أ)

\begin{tabular}{|c|c|c|}
\hline \multicolumn{3}{|c|}{ لطلاب). } \\
\hline تصويبها & تحديد الأخطاء & 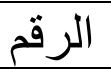 \\
\hline كثيرة & كاسي رة / كانثيرة / كثثرة / كثيرت / كثيرة / كاسيرة / كثير اة / كسرة / كثيرة & 1 \\
\hline القر اعة & 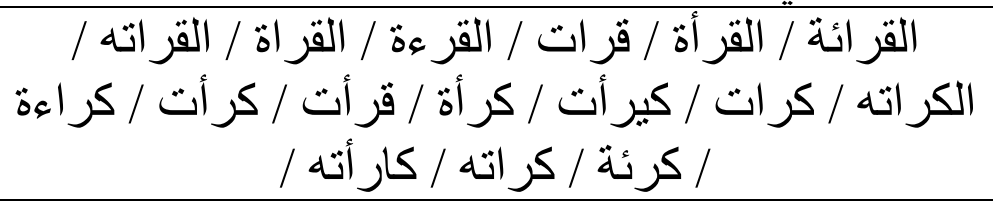 & 2 \\
\hline 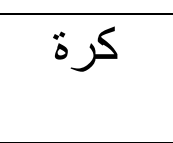 & كرتل / كرتل / كورة / كرتل / قرة / قرت / كر / كر / / كرت / كرت & 3 \\
\hline 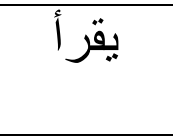 & 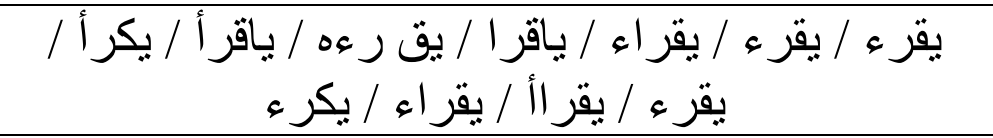 & 4 \\
\hline 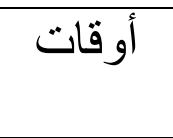 & اوقات / أوقت / اوكة / اوقتل / أوقتل / اوقت / اوكاتل / & 5 \\
\hline يأخذ & ياءخذ / يئخذ / يؤخذ / ياءخوذوه / يئخوذو / يوخذ / ياخذ / & 6 \\
\hline أسبوع & 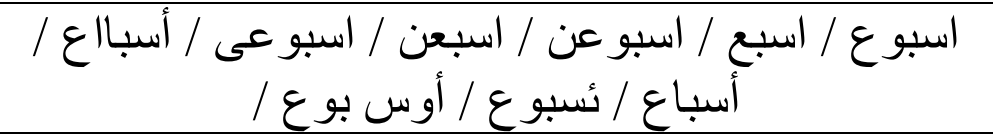 & 7 \\
\hline أيام & 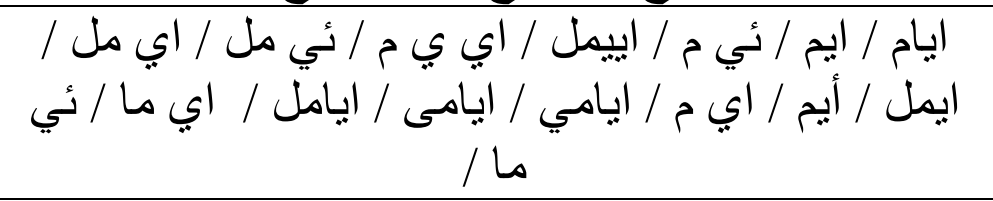 & 8 \\
\hline إلى & الى / ائل / ال ى / ال / ال / / الا / & 9 \\
\hline أي اي & ايي / ايا / اي / اين / عي / أيء / اييه / ايأ / ئي / ايى & 10 \\
\hline رسومة & 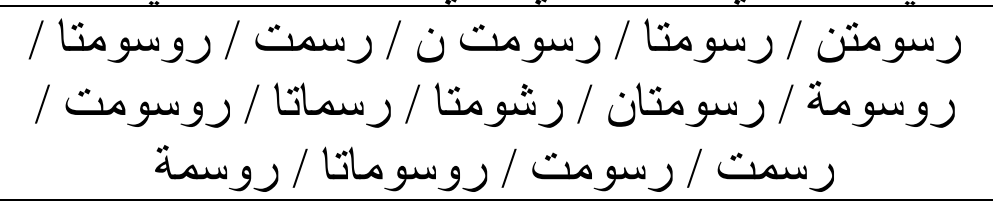 & 11 \\
\hline
\end{tabular}




\begin{tabular}{|c|c|c|}
\hline الأشجار & 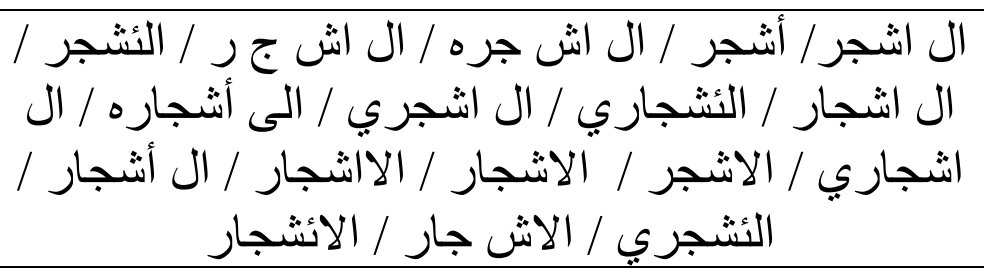 & 12 \\
\hline جيدة & جيدت / جي دة / جيداة / جيداة / جيدةن / جيد / جيدات / جي / جي / جي & 13 \\
\hline جائزة & (جائزت، جاءزت، جئزت، جأزة، جائزةنا، جاززت) & 14 \\
\hline دائما & داعما / داما / داءم / دام / دايمن / دامن / داعيما / داي م / دإما & 15 \\
\hline المجلات & المجلى ت & 16 \\
\hline ذهابا & ذهاب 1 & 17 \\
\hline كتابا & كتبا & 18 \\
\hline
\end{tabular}

2) الأخطاء الإملائية في مهارة الكتابة لطالبات الصف الثاني (في الصف الثامن

\begin{tabular}{|c|c|c|}
\hline \multicolumn{3}{|c|}{ (ج) لطالبات). } \\
\hline تصويبها & تحديد الأخطاء & 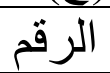 \\
\hline كثيرة & كثيرة / كثرة / كثر اة / كثير اة / كسيرة & 1 \\
\hline 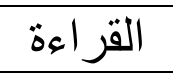 & القرعة / القر أة / ال قر أة & 2 \\
\hline 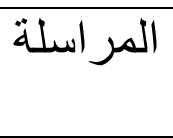 & المر اسلاة / المور اسلته / ال مرسلة / المر اسلت / المرسلاة & 3 \\
\hline يقر أ & يقر اء / يقر / / يقر / / يكر أ & 4 \\
\hline 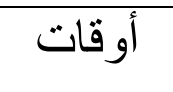 & اوقات / اوقت / اوق ت / اوق ات / اوقة / اوقاة & 5 \\
\hline 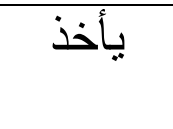 & ياءخذ / ي أخذ / يئخذ / يااءخذ / يؤخذ / ي أخ ذ / & 6 \\
\hline أسبوع & اس بوع / اسبوع / اسبع & 7 \\
\hline أيام & 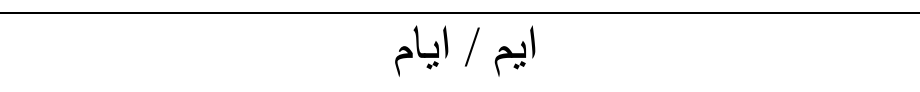 & 8 \\
\hline إلى & الى / الي / ال / ال ى/ الا / ال ي & 9 \\
\hline أي & ايي / ايا / ايي / اي / اي ي / ايى / اييا / ايا / ايي & 10 \\
\hline رسومة & رسومت / رسو مت / رسو مت / رسومتا / رس وم & 11 \\
\hline
\end{tabular}




\begin{tabular}{|c|c|c|}
\hline & ت & \\
\hline الأشجار & 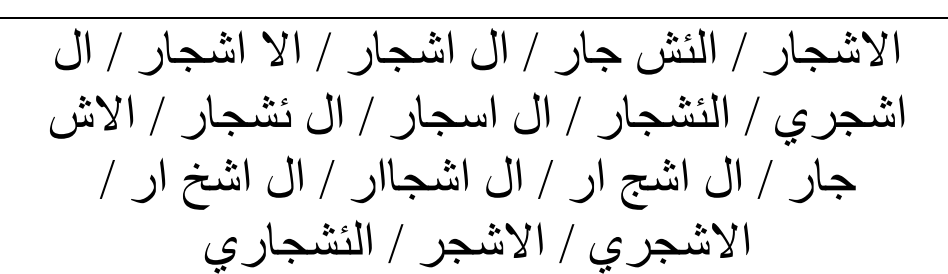 & 12 \\
\hline 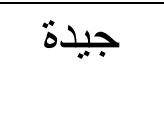 & جيداة / جييدت / جييدة / جي دة / جيدة / جي يدت / جيد / & 13 \\
\hline جائزة & جئزة / جاءز ات / جاءزة / جائز اة / جاءزة / جائزة / جؤزة & 14 \\
\hline دائما & داءما / دائم / داءم I / دائم I / دعم I / دأما / دإما / دام I & 15 \\
\hline 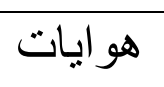 & 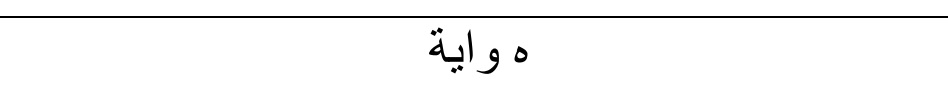 & 16 \\
\hline 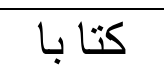 & كتاب اب ال كت & 17 \\
\hline
\end{tabular}

3.تصنيف الأخطاء: إن عملية تصنيف الأخطاء تتطلب منا مرونة كبيرة، وأن

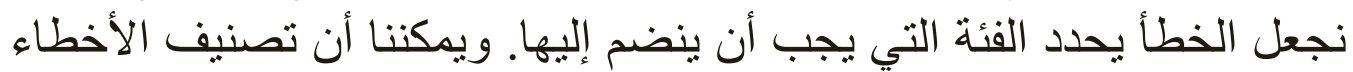

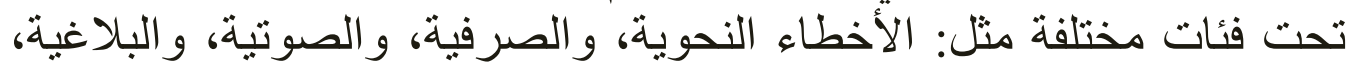

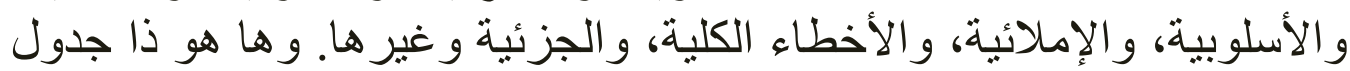

\begin{tabular}{|c|c|c|c|}
\hline & & & \\
\hline حطاء & الرجد & تصسيق الا & الرقح \\
\hline التاء المفتوحة & 2 & التاء المربوطة & 1 \\
\hline الهمزة في وسط الكلمة & 4 & الهمزة في أول الكلمة & 3 \\
\hline وصل الحروف وفصلها & 6 & الهمزة في آخر الكلمة & 5 \\
\hline
\end{tabular}

4.وصف الأخطاء: لقد أوجد محللو الأخطاء أربع فئات لوصف الأخطاء وهي

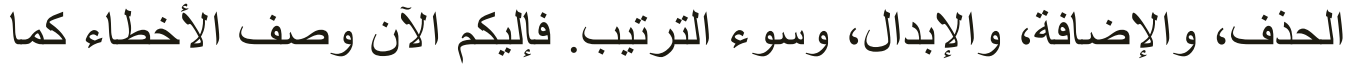

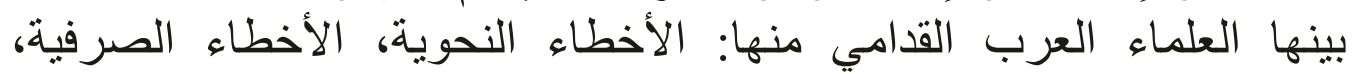
الأخطاء الصوتية، الأخطاء الَّلاغية، الأخطاء الأسلوبية، الأخطاء الأبهاء المعجمية، الأخطاء الإملائية، الأخطاء الكلية، الأخطاء الألئية الأئية.

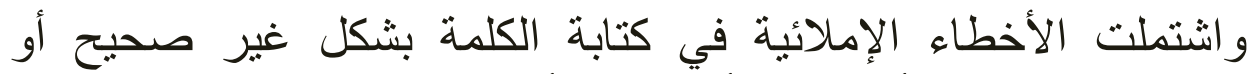

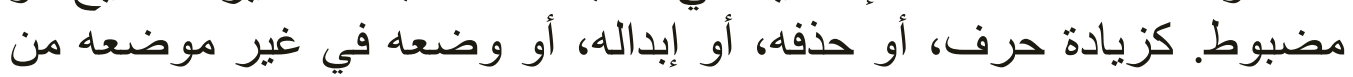

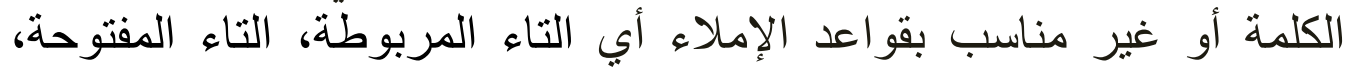


الهمزة في أول الكلمة، الهمزة في وسط الكلمة، الهمزة في آخر الكلمة، و ولهئ

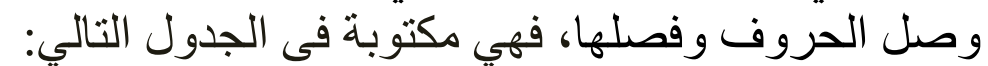
1)وصف على الأخطاء الإملائية في مهارة الكتابة لطلاب الصف الطف الثاني (في الصف الثامنة (أ) لطلاب).

\begin{tabular}{|c|c|c|}
\hline وصفها & تحديد الأخطاء & 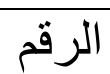 \\
\hline \multirow{3}{*}{ التاء المربوطة الت } & ك س ر ت / كثيرت & 1 \\
\hline & قر ات / كر ات / كير أت / قر أت / كر أت & 2 \\
\hline & قرت / كرت / قورت / كرتل / قر اتل & 3 \\
\hline \multirow{4}{*}{ التاء المربوطة الت } & 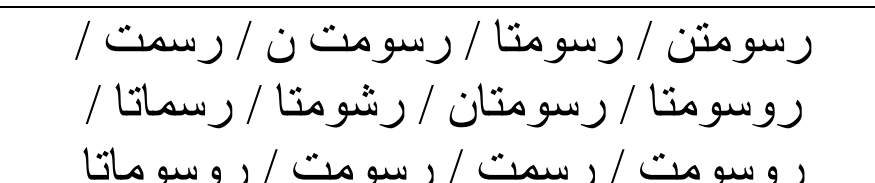 & 4 \\
\hline & جيدت / جيدات / جيدت ن / & 5 \\
\hline & | & \\
\hline & جائزت / جاءزت / جئزت / جائزنا / جازت & 6 \\
\hline \multirow[t]{2}{*}{ التاء المفتوحة } & اوكة / اوقة & 7 \\
\hline & المجلة & 8 \\
\hline الهزة في أولة & اوقات / أوقت / اوكة / اوقتل / أوقتل / اوقت / اوقة / اوقاتل & 9 \\
\hline الهزة في أول & 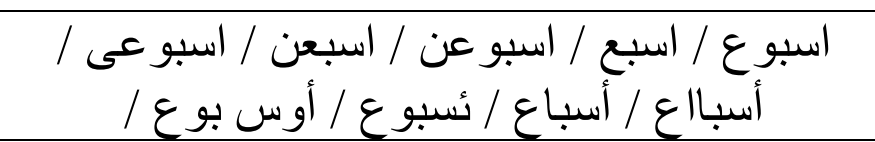 & 10 \\
\hline 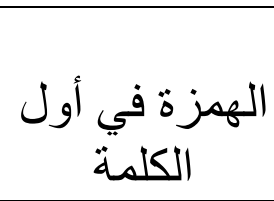 & 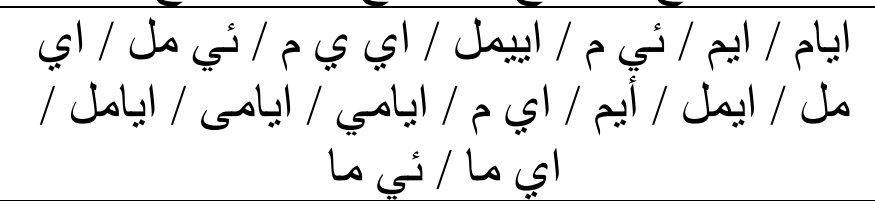 & 11 \\
\hline الهمزة في أول & الى / ئل / ال ى / ال / ال ا / الا & 12 \\
\hline المزة في أول & ايي / ايا / اي / اين / عي / أيء / اييه / ايأ / ايى & 13 \\
\hline الهمزة في أول & 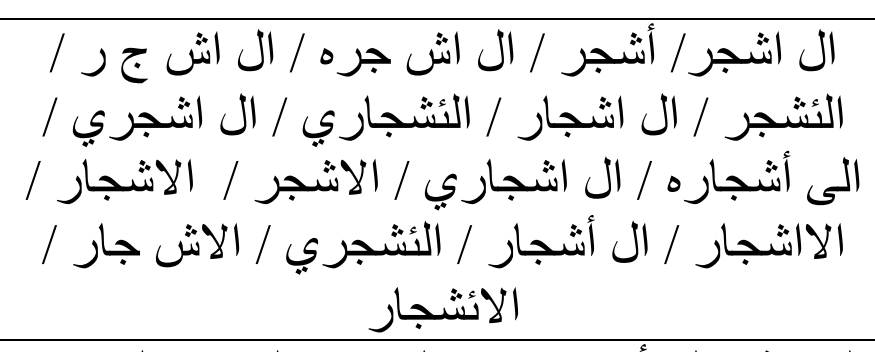 & 14 \\
\hline & القرائة / القر أة / قر ات / القرعة / القر اة / القر اته / & 15 \\
\hline
\end{tabular}




\begin{tabular}{|c|c|c|}
\hline الهزة في وسطة & 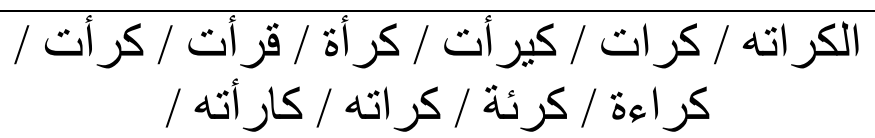 & \\
\hline الهمزة في وسط الكلمة & 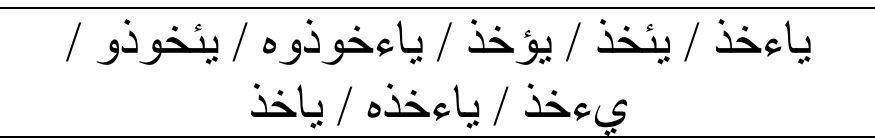 & 16 \\
\hline الهمزة في وسط الكلمة & جاءزة / جأزة / جئزة / جائزت / جائز / جاءزت / جائز / جائز & 17 \\
\hline الهمزة في وسط الكلمة & داءما / داما / داءم / دام / دايمن / دامن / داعيما / د د د د د & 18 \\
\hline الهمزة في آخر & 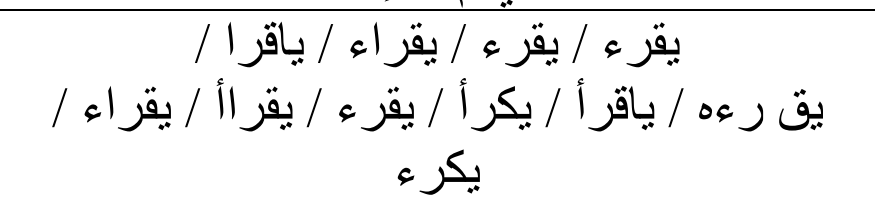 & 19 \\
\hline \multirow{7}{*}{ وصل الحروف } & ك س رت / كاسي رة /كاسيرة / كايرة & 20 \\
\hline & يق رعه & 21 \\
\hline & المجلى ت & 22 \\
\hline & أوس بوع & 23 \\
\hline & اي ي م & 24 \\
\hline & ذهاب | & 25 \\
\hline & ال الى / ال ا & 26 \\
\hline وصل الحروف & 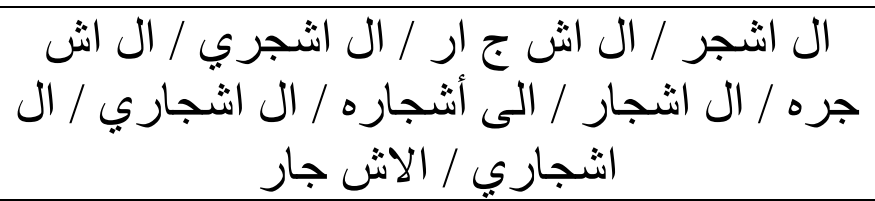 & 27 \\
\hline وصل الحروف & جي دة / جيءدة / جي داة / & 28 \\
\hline فصل الحرف & 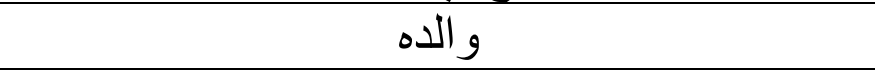 & 29 \\
\hline
\end{tabular}

2) وصف على الأخطاء الإملائية في مهارة الكتابة لطالبات الصف الثاني

\begin{tabular}{|c|c|c|}
\hline & \multicolumn{2}{|c|}{ (في الصف الثامنة (ج) لطالبات). } \\
\hline وصفها & تحديد الأخطاء & 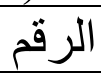 \\
\hline \multirow[t]{4}{*}{ التاء المربوطة } & المر اسلت & 1 \\
\hline & رسومت / رسو مت / رسو مت / رسومتا / & 2 \\
\hline & جييدت / جي يدت / جي ي دت / جيدت & 3 \\
\hline & جاءز ات / جائزت & 4 \\
\hline
\end{tabular}




\begin{tabular}{|c|c|c|}
\hline \multirow[t]{3}{*}{ التاء المفتوحة } & هواية & 5 \\
\hline & اوقة / اوقاة & 6 \\
\hline & و المجلاة & 7 \\
\hline \multirow{3}{*}{ الهزة في أول } & اوقات / اوقت / اوق ت / اوق ات / اوقة / & 9 \\
\hline & اس بوع / اسبوع / اسبع & 10 \\
\hline & ايم / ايام & 11 \\
\hline \multirow[b]{2}{*}{ الهمزة في أول } & اللى/ الي / ال / ال ى الا / ال ي & 12 \\
\hline & ايي / ايا / ايي / اي / اي ي / ايیى / اييا / ايا / & 13 \\
\hline الهمزة في أول & 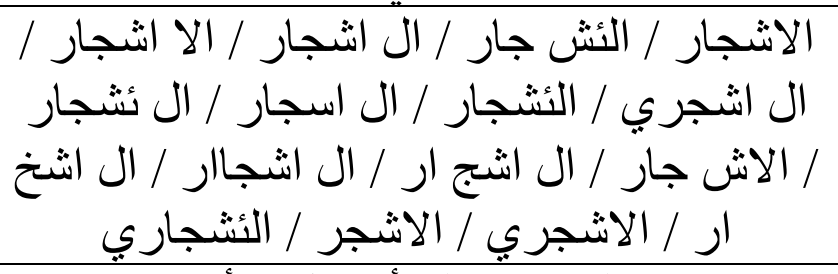 & 14 \\
\hline الهززة في وسطة & القرعة / القرأة / ال قرأة & 15 \\
\hline الهمزة في وسط الكلمة & ياءخذ / ي أخذ / يئخذ / ياءخذ / يؤخذ / ي أخ & 16 \\
\hline \multirow[t]{2}{*}{ الهمزة في وسط الكلمة } & جئزة / جاءز ات / جاءزة / جائز اة / جاءزة / جزة / جاءة & 17 \\
\hline & 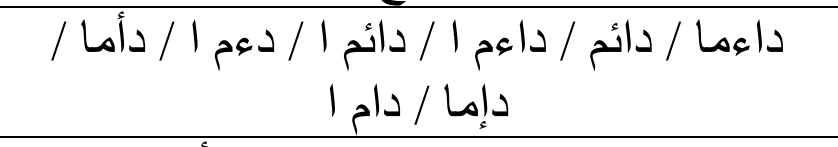 & 18 \\
\hline الهمزة في آخر & يقر اء / يقر \& / يقر / / يكر أ & 19 \\
\hline \multirow{10}{*}{ وصل الحروف } & هواية & 20 \\
\hline & ال قر أة & 21 \\
\hline & ال ال مرسلة & 22 \\
\hline & اوق ت اوق ات & 23 \\
\hline & ي أ خذ/ ي أ خذ & 24 \\
\hline & كتاب & 25 \\
\hline & اس بوع & 26 \\
\hline & ل ال ى / ال ي & 27 \\
\hline & رسو م ت /رس وممت & 28 \\
\hline & الئش جار / الاش جار / ال اش ج ار / ال I & 29 \\
\hline
\end{tabular}




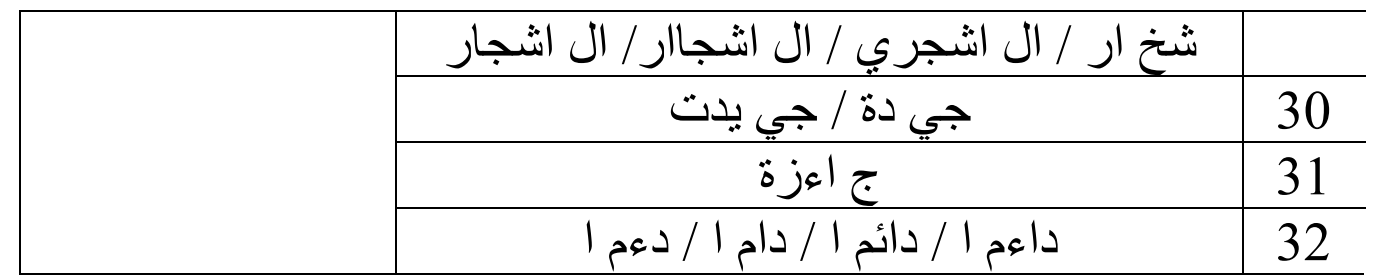

5. شرح الأخطاء: أن نعزو هذه الأخطاء إلى مظانها الرئيسة. أي أن نبين دليلها مناسبا بالقو اعد الإملائية.

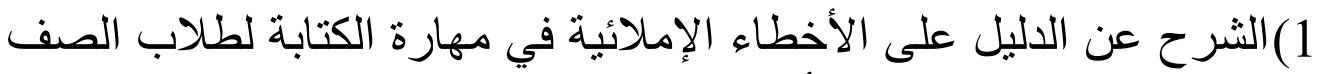
الثاني (في الصف الثامنة (أ) لطلاب).

\begin{tabular}{|c|c|c|}
\hline شرحها & تحديد الأخطاء & 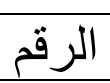 \\
\hline \multirow{6}{*}{ كتب الطالب بالتاء } & ك س ر ت / كثيرت & 1 \\
\hline & قر ات / كرات / كير أت / قرأت /كر أت & 2 \\
\hline & قرت / كرت / قورت / كرتل / قراتل & 3 \\
\hline & 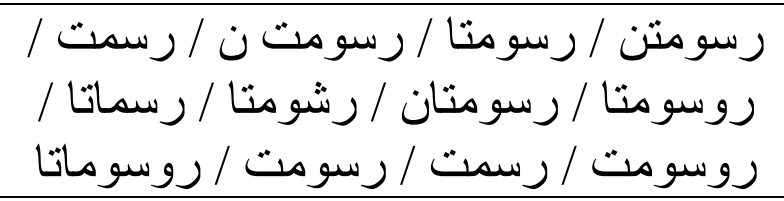 & 4 \\
\hline & جيدت / جيدات / جيدت ن / ج ي دت & 5 \\
\hline & جائزت / جاءزت / جئزت / جائزتا / جاازت & 6 \\
\hline
\end{tabular}

\begin{tabular}{|c|c|c|}
\hline شرحها & تحديد الأخطاء & الرقم ل \\
\hline كتب الطالب بالتاء & اوكة / اوقة & 1 \\
\hline المربوطة & المجلة & 2 \\
\hline
\end{tabular}

\begin{tabular}{|c|c|c|}
\hline شرحها & تحديد الأخطاء & 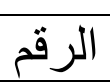 \\
\hline \multirow[t]{2}{*}{ كتب الطالب بالألف } & اوقات / اوكة / اوقتل / اوقت / اوكاتل / اوقة & 1 \\
\hline & ايام / ايم / اييمل / اي ي م / ايامي / اي مل / ايامل / اي مل / ايمل / & 2 \\
\hline كتب الطالب بالألف & اسبو ع / اسبع / اسبو عن / اسبعن / اسبو عى / & 3 \\
\hline \multirow[t]{2}{*}{ كتب الطالب بالألف } & الى / ال ع / ال / ال I / الا / & 4 \\
\hline & ايي / ايا / اي / اين / اييه / ايأ / ايى & 5 \\
\hline كتب الطالب بالألف & 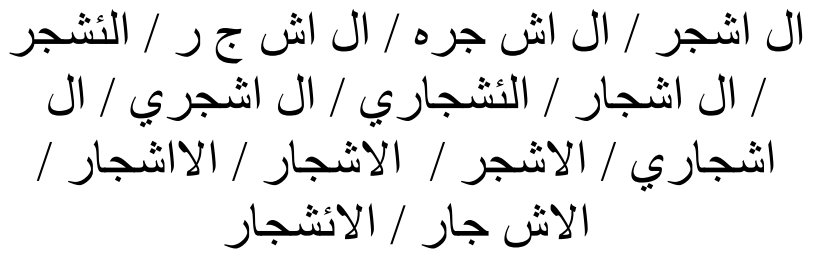 & 6 \\
\hline
\end{tabular}




\begin{tabular}{|c|c|c|}
\hline شرحها & تحديد الأخطاء & 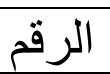 \\
\hline كتب الطالب بالألف & قرات / القر اة / القر اته / الكر اته / كر ات / / & 1 \\
\hline كتب الطالب بالألف & باخذ & 2 \\
\hline \multirow[t]{2}{*}{ كتب الطالب بالألف } & جازت & 3 \\
\hline & داما / دام / دايمن / دامن / داي م & 4 \\
\hline
\end{tabular}

\begin{tabular}{|c|c|c|}
\hline شرحها & تحديد الأخطاء & الرقم \\
\hline كتب الطالب بالألف & ياقر ا & 1 \\
\hline
\end{tabular}

\begin{tabular}{|c|c|c|}
\hline شرحها & تحديد الأخطاء & 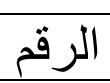 \\
\hline \multirow{6}{*}{ كتب الطالب بفصل } & ك س رت / كا سي رة / كا سيرة / كا ثيرة & 1 \\
\hline & يق رعه / المجلى ت & 2 \\
\hline & ذهاب ا / ال ى / ال I & 3 \\
\hline & أوس بوع / اي ي م & 4 \\
\hline & 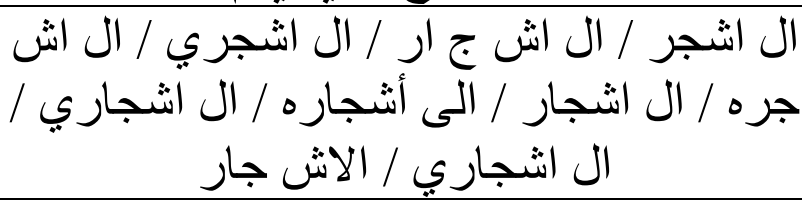 & 5 \\
\hline & جي دة / جي ودة / جي داة / ج ي دت & 6 \\
\hline كتب الطالب بوصل & و الده & 7 \\
\hline
\end{tabular}

2)شرح عن الدليل على الأخطاء الإملائية في مهارة الكتابة لطالبات الصف (جات الصات الثاني (في الصف الثنامنة (ج) لطالبات).

\begin{tabular}{|c|c|c|}
\hline شرحها & تحديد الأخطاء & 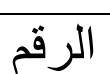 \\
\hline \multirow{4}{*}{ كتبت الطالبة بالتاء } & المر اسلت & 1 \\
\hline & رسومت / رسو م ت / رسو مت / رسومتا / & 2 \\
\hline & جييدت / جي يدت / جي ي دت / جيدت & 3 \\
\hline & جاءز ات / جائزت & 4 \\
\hline
\end{tabular}

\begin{tabular}{|c|c|c|}
\hline شرحها & تحديد الأخطاء & الرقم \\
\hline كتبت الطالبة بالتاء & مواية & 1 \\
\hline المربوطة & اوقة / اوقاة & 2 \\
\hline
\end{tabular}




\begin{tabular}{|c|c|c}
\hline & 3 \\
\hline
\end{tabular}

\begin{tabular}{|c|c|c|}
\hline شرحها & تحديد الأخطاء & الرقم \\
\hline كتبت الطالبة بالألف & اوقات / اوقت / اوق ت / اوق ات / اوقة / & 1 \\
\hline كتبت الطالبة بالألف & ايم / ايام / اس بوع / اسبوع / اسبع & 2 \\
\hline \multirow[t]{2}{*}{ كتبت الطالبة بالألف } & الى/ الي / ال / ال ى/ الا / ال ي & 3 \\
\hline & ايي / ايا / ايي / اي / اي ي / ايى / اييا / ايا / & 4 \\
\hline كتبت الطالبة بالألف & 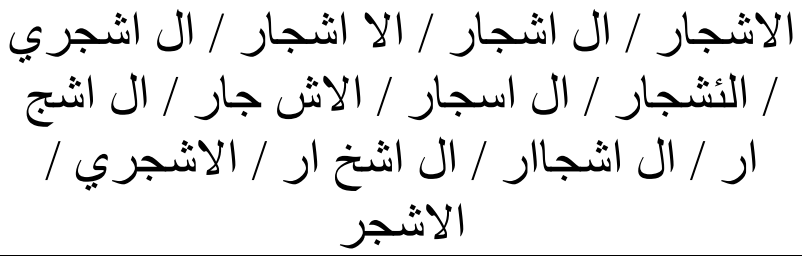 & 5 \\
\hline
\end{tabular}

\begin{tabular}{|c|c|c|}
\hline شرحها & تحديد الأخطاء & الرقم - الر \\
\hline \multirow[t]{2}{*}{ كتبت الطالبة بالألف } & دام 1 & 1 \\
\hline & يقر ا & 2 \\
\hline
\end{tabular}

\begin{tabular}{|c|c|c|}
\hline كتبت الطالبة بفصل شرها & تحديد الأخطاء & 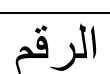 \\
\hline \multirow{6}{*}{ كتبت الطالبة بفصل } & هواية / ال قر أة / ال مرسلة / كتاب ا & 1 \\
\hline & اوق ت / اوق ا ت / ي أ خذ/ ي أ خذ & 2 \\
\hline & اس بوع / ال ى / ال ي / رسو م ت / & 3 \\
\hline & 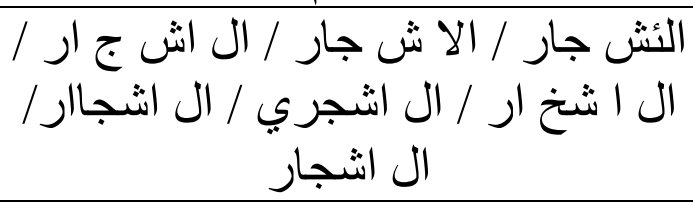 & 4 \\
\hline & جي دة / جي يدت / ج اعزة & 5 \\
\hline & داءم I / دائم I / دام I / دعم I & 6 \\
\hline
\end{tabular}

6. تصويب الأخطاء بعد جمع الأخطاء وتحديدها وتصنيفها ووصفها وشرحهاء الأنها، حانت الخطوة

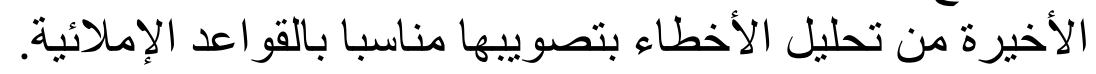

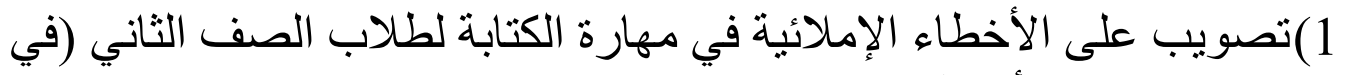
الصف الثامنة (أ) لطلاب). 
التاء المربوطة

\begin{tabular}{|c|c|c|}
\hline تصويبها & تحديد الأخطاء & الرقم \\
\hline أن تكتب بالتاء المربوطة (ة) لأنها في & ك س ر ت / كثيرت & 1 \\
\hline كثهيرة/جيدة. الصفة المؤنثة. فتصويبهماً: & جيدت / جيدات / جيدت ن / ج دت & 2 \\
\hline أن تكتب فاءت في آخر الاسم المربوطة (ة) لأنها & قر ات / كر ات / كر أت أت / & 3 \\
\hline كرة. المؤنث لفظا. فتصويبهما: القراءة، & قرت / كرت / قرت / / & 4 \\
\hline 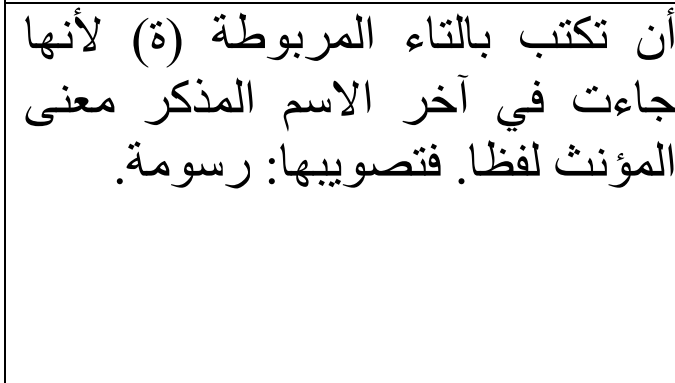 & 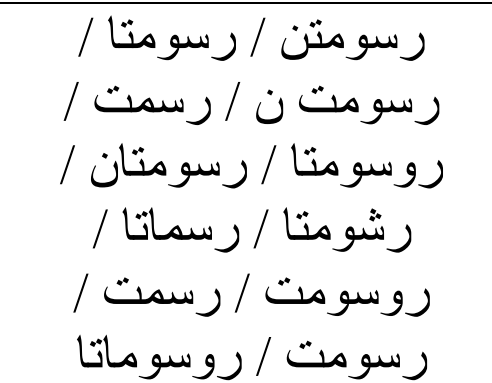 & 5 \\
\hline 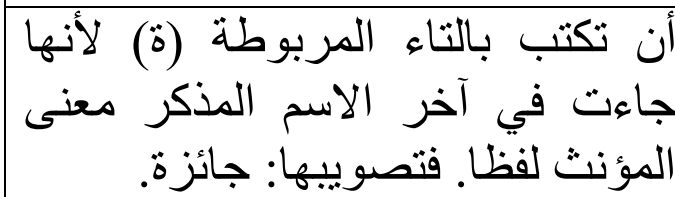 & جائزت / جاءز / جائز / جائزت / جازت & 6 \\
\hline
\end{tabular}

2) التاء المفتوحة

\begin{tabular}{|c|c|c|}
\hline تصويبها & حديد الاخطاء & الرقم \\
\hline أن تكتب بالتاء المفتوحة أو التاء التأنيث & اوكة / اوقة & 1 \\
\hline 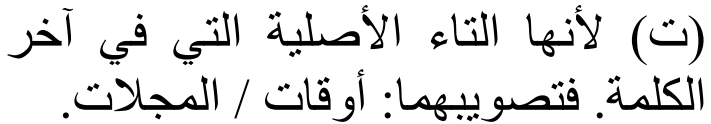 & المجلة & 2 \\
\hline
\end{tabular}

3) الهمزة في أول الكلمة

\begin{tabular}{|c|c|c|}
\hline تصويبها & تحديد الأخطاء & الرقم \\
\hline 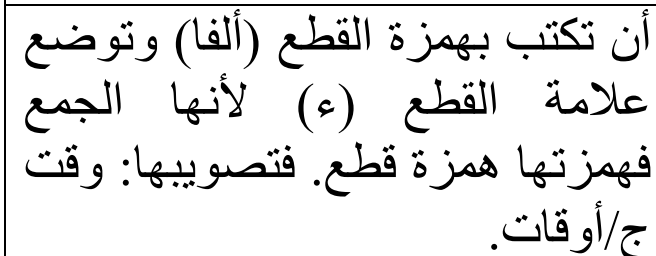 & / أوقات / أوقت / اوقت / اوكاتل / اوقتل / اوقل & 1 \\
\hline 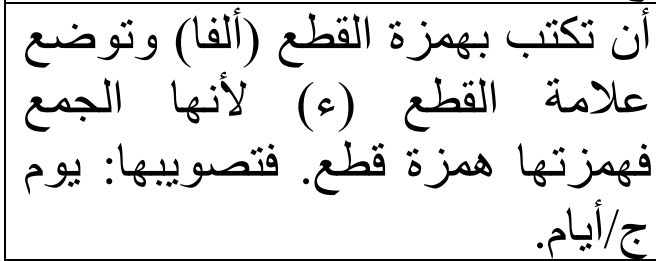 & 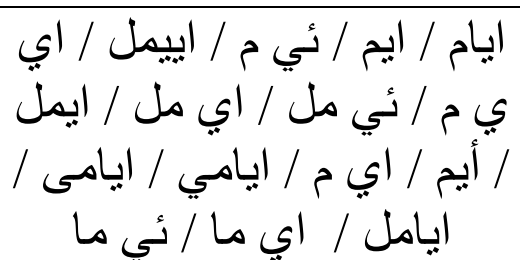 & 2 \\
\hline 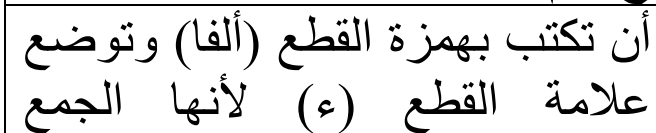 & جره / ال اش / أشجر / الث اش / الشجر & 3 \\
\hline
\end{tabular}




\begin{tabular}{|c|c|c|}
\hline 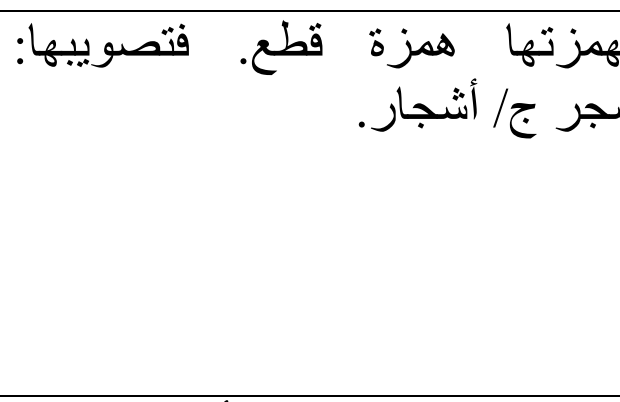 & 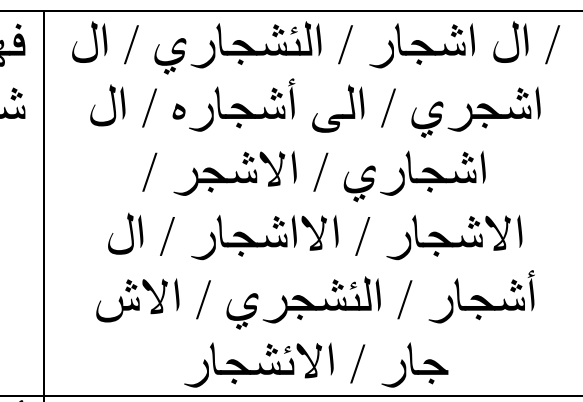 & \\
\hline 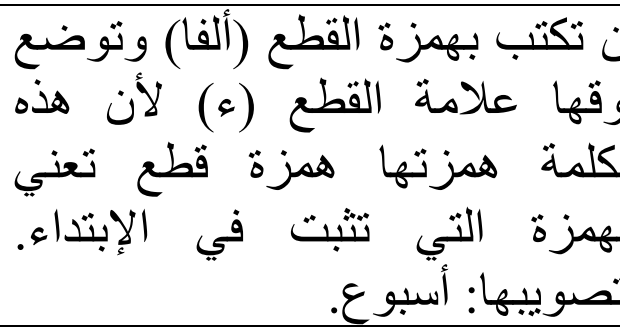 & أسبعن / اسبوع / اسبع / اسبوع / أسباع / / أسبوع / أوس بوع / أسبوع / أسبوع & 4 \\
\hline 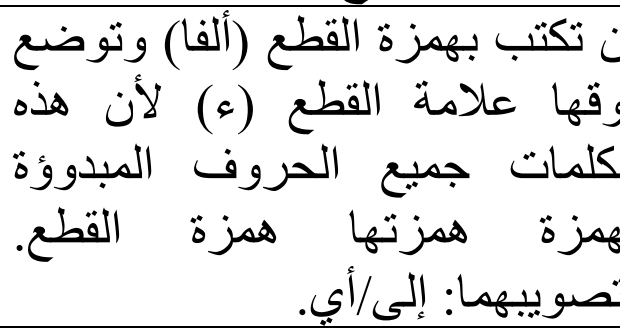 & 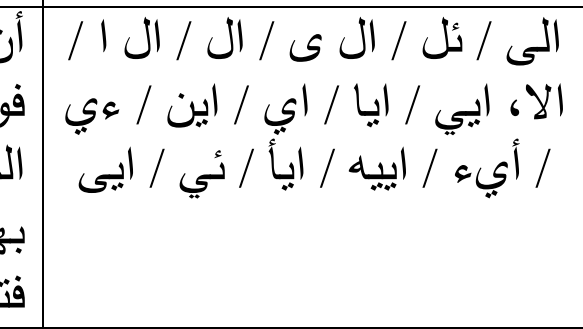 & 5 \\
\hline & زة في وسط الكلمة & 4) الهه \\
\hline تصويبها & تحديد الأخطاء & الرقم \\
\hline 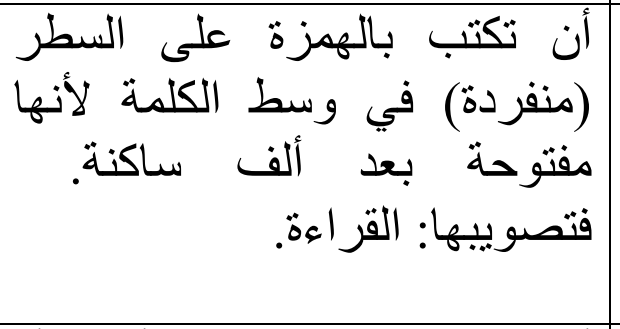 & 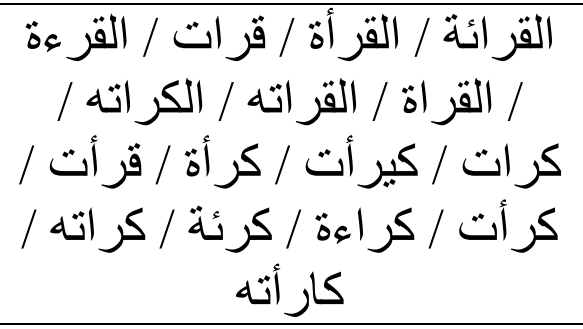 & 1 \\
\hline 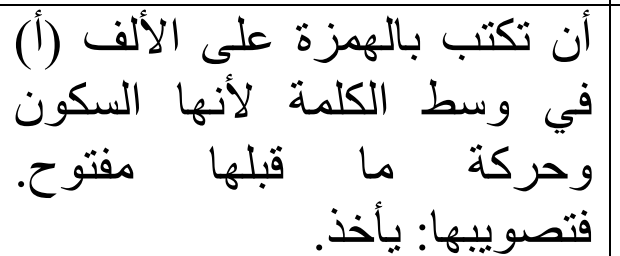 & 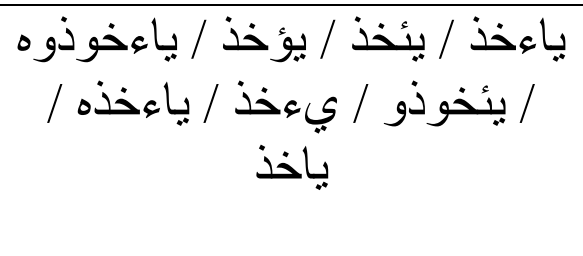 & 2 \\
\hline 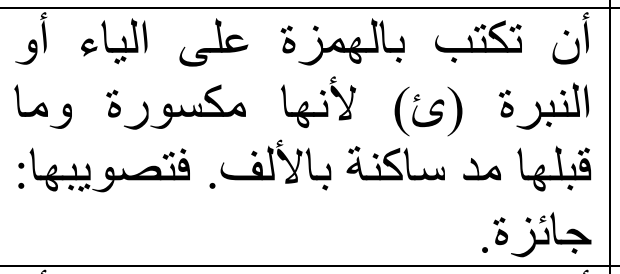 & / جاءزة / جأزة / جئزة / جائزت / جائزتا / جائز & 3 \\
\hline 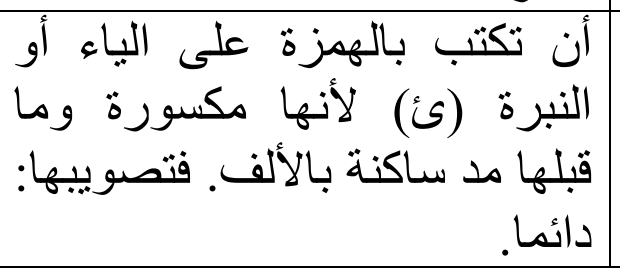 & / داعما / داما / داءم / داع / دام / دايمن / داما مايما & 4 \\
\hline
\end{tabular}




\begin{tabular}{|c|c|c|}
\hline \multicolumn{3}{|c|}{ 5) الهمزة في آخر الكلمة } \\
\hline تصويبها & تحديد الأخطاء & الرقم \\
\hline ر أ. سبقها حرف مفتهز المتطرفة على الألف & 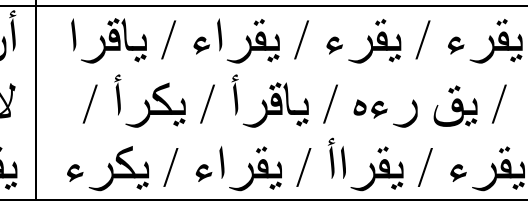 & 1 \\
\hline \multicolumn{3}{|c|}{ 6) وصل الحروف وفصلها } \\
\hline تصويبها & تحديد الأخطاء & الرقم \\
\hline 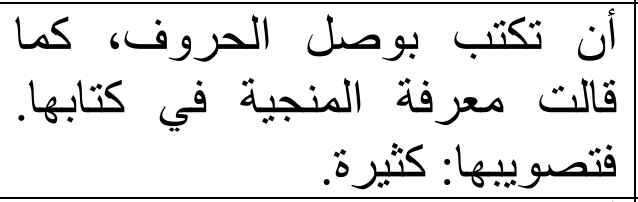 & ك س رت / كاسرة / كا ثيرة رة / كا & 1 \\
\hline 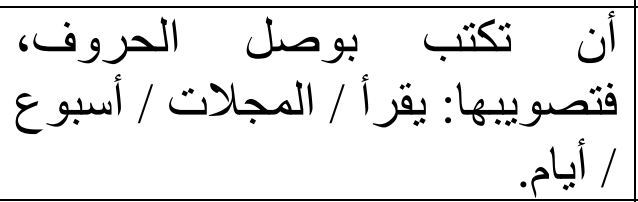 & يق رعه / المجلى ت / أوس / أي م & 2 \\
\hline فتصوي تكها: ذهابا / إلى & ذهاب I / ال ى / ال I & 3 \\
\hline فتصويبها: الأشجار بوصل الحروف، & 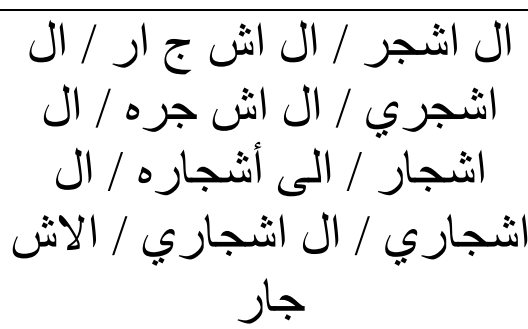 & 4 \\
\hline فتصويبها: جيدة بوصل الحروف، & جي دة / جيعدة / جي داة / ج & 5 \\
\hline 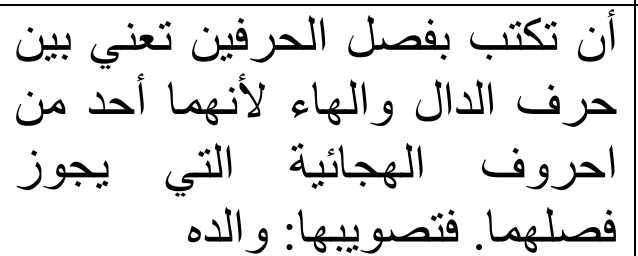 & و الده & 6 \\
\hline
\end{tabular}

2) تصويب على الأخطاء الإملائية في مهارة الكتابة لطالبات الصف الثاني (1) الصي الصف الثامنة (ج) لطالبات). 1 التاء المربوطة المبف

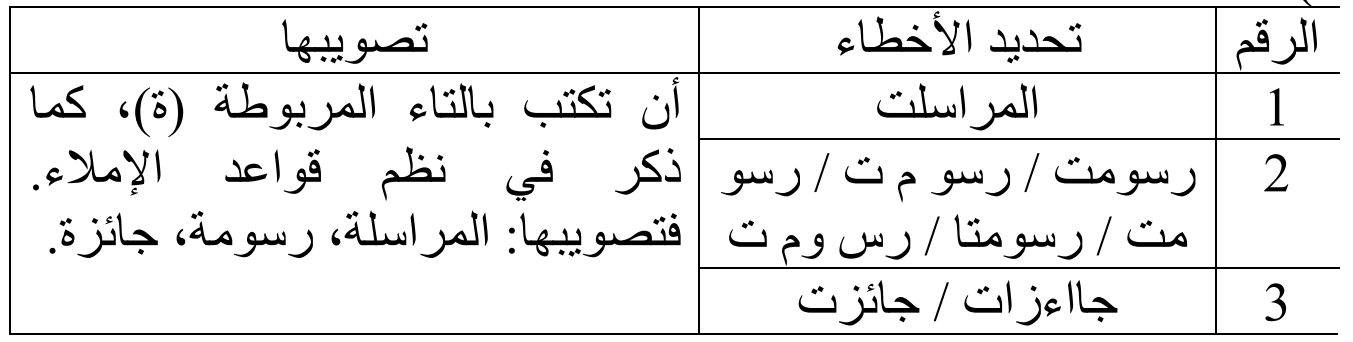




\begin{tabular}{|c|c|c|}
\hline نهاية أنتب بالتاء المربوطة (ة) لأنها فئي & جييدت / جي يدت / جي ي & 4 \\
\hline & المفتوحة & 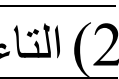 \\
\hline تصويبها & تحديد الأخطاء & الرقم \\
\hline تكتب بالتاء المفتوحة أو التاء التأنيث & مواية / اوقة & 1 \\
\hline ) لأنها التاء الأصلية التي في آخر & اوقاة & 2 \\
\hline جلات. فتصويبها: هوايات، أَوقات، & و المجلاة & 3 \\
\hline & ة في أول الكلمة & 3) - 3 الهم \\
\hline تصويبها & تحديد الأخطاء & الرقم \\
\hline علامة تكتب القهزة القطع (ألفا) وتوضع الأنها & اوقات / اوقت / اوق / اوقة / اوقاة / اوق اوقاة & 1 \\
\hline فهززتها همزة قطع. فتصويبها: وقت & ايم / ايام & 2 \\
\hline 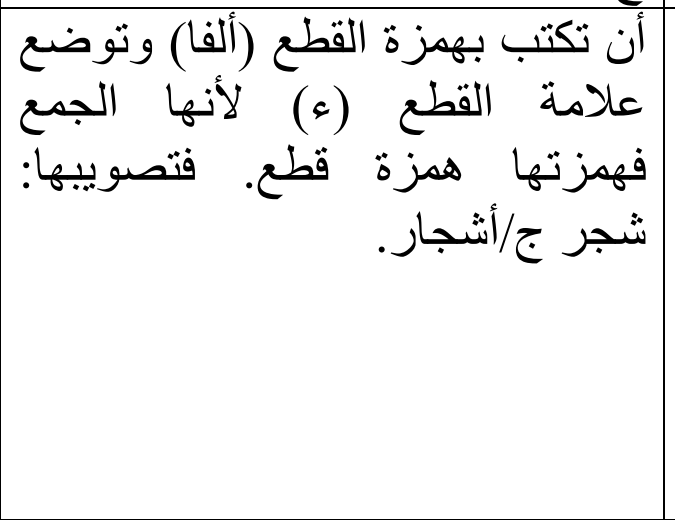 & 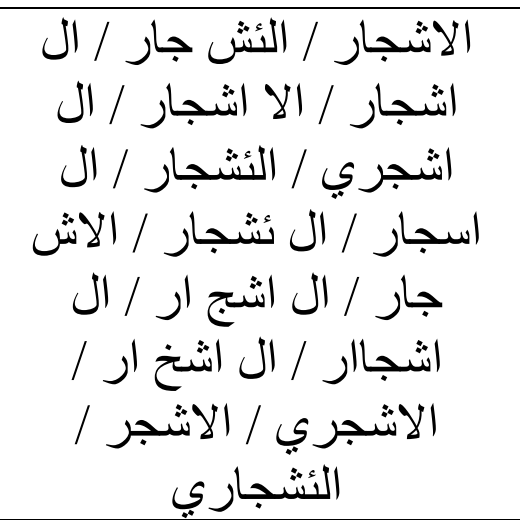 & 3 \\
\hline 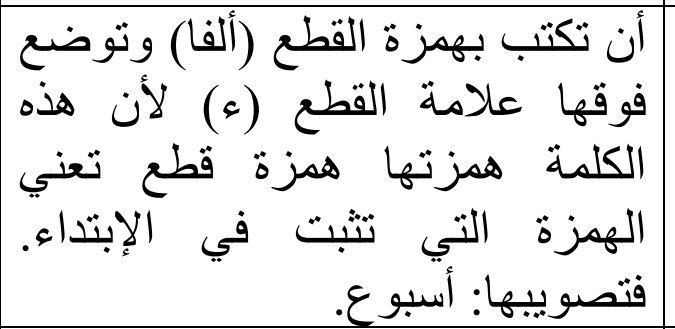 & اس بوع / اسبوع / اسبع & 4 \\
\hline فو فها علامة بهزة القطع (ء) (ألفا) وتوضع فال & الى/ الي / ال / ال ى/ الا / & 5 \\
\hline 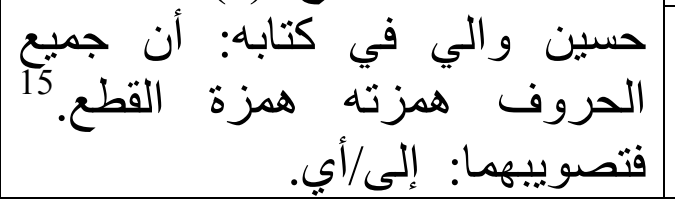 & ايي / ايا / ايي / ائي / اي / ايبي / ايب / ايب / ايب / & 6 \\
\hline
\end{tabular}

${ }^{15}$ حسين و الي، كتاب الإملاء، (بيروت لبنان: دار الكتب العلمية، 1987م)، ص. 40 (1967) 4015 
4) الهمزة في وسط الكلمة

\begin{tabular}{|c|c|c|}
\hline تصويبها & تحديد الأخطاء & 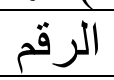 \\
\hline 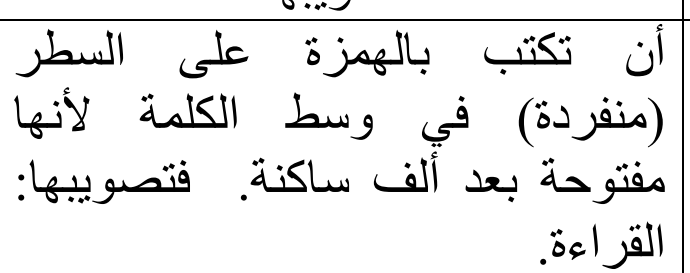 & القزعة / الَقرأَة / ال قر أة & 1 \\
\hline 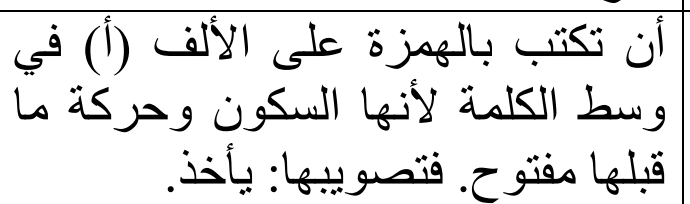 & 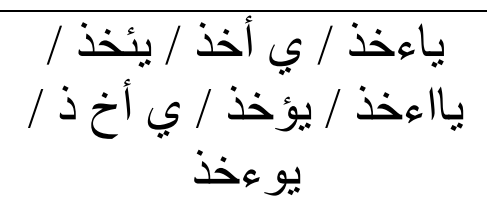 & 2 \\
\hline 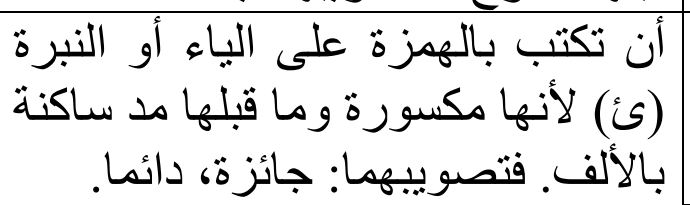 & 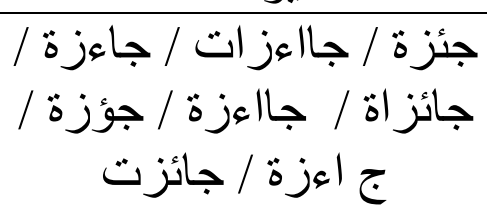 & 3 \\
\hline & 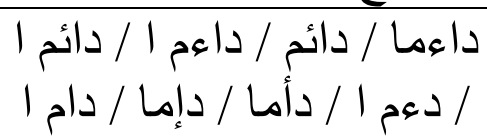 & 4 \\
\hline \multicolumn{3}{|c|}{ (الهمزة في آخر الكلمة } \\
\hline تصويبها & " تحديد الأخطاء & 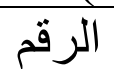 \\
\hline تكبقب بالهمزة المنطرفة على حفتى الألف & يقر اء / يقرء / يقر | / يكرأ & 1 \\
\hline
\end{tabular}

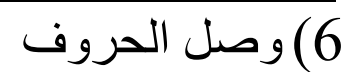

\begin{tabular}{|c|c|c|}
\hline تصويبها & تحديد الاخطاء & الرقم \\
\hline 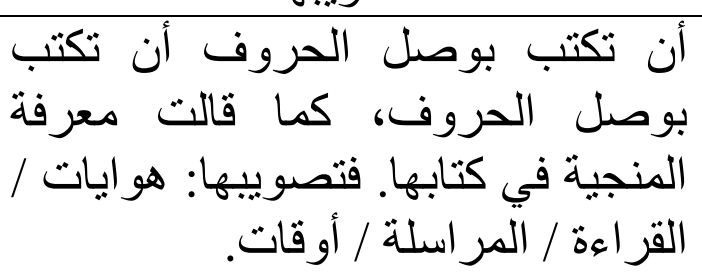 & مرسلة / اوق ت ت / اوق ال ال & 1 \\
\hline 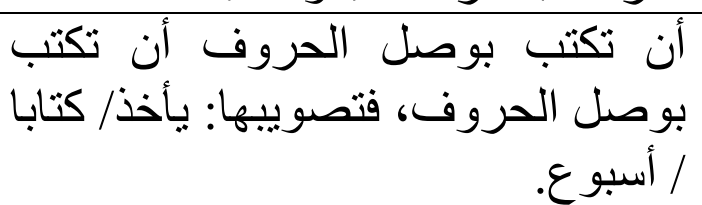 & 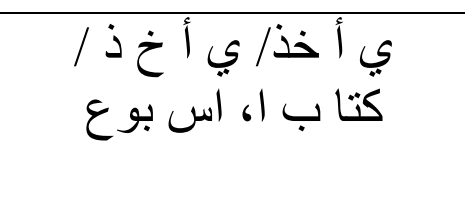 & 2 \\
\hline أن تكتب الحروف، فتصويبها: إلى تكتب ز & ال / / ال ي / رسو مت ت & 3 \\
\hline بوصل أنب تبروف، فتصويبها: الأشجار. تكروف & 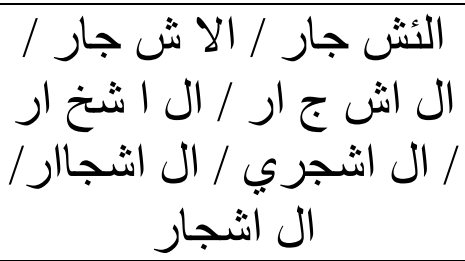 & 4 \\
\hline تكتر & & 5 \\
\hline
\end{tabular}




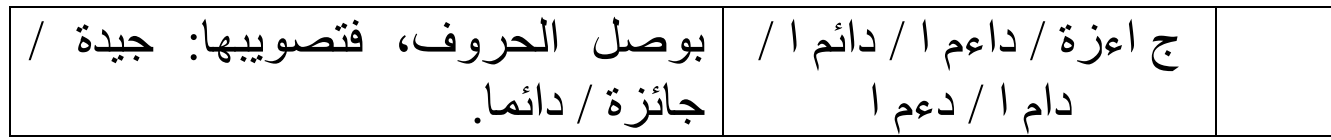

بالألف اللينة دائمل: فثى، يشترى / في، الاختتام

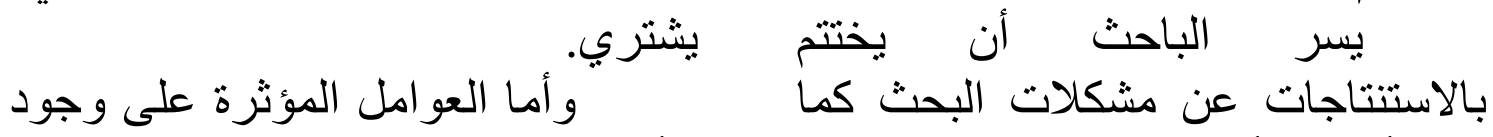

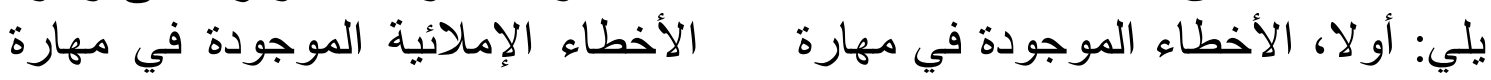

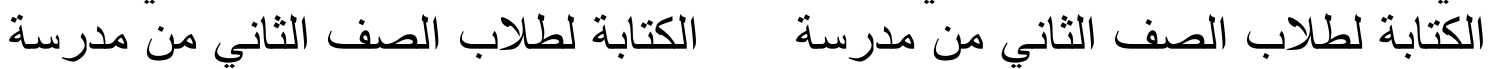

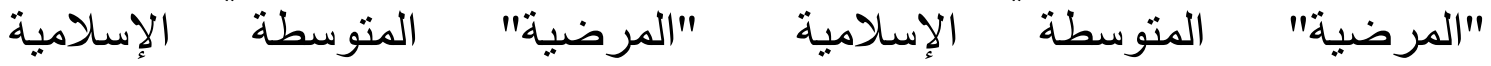

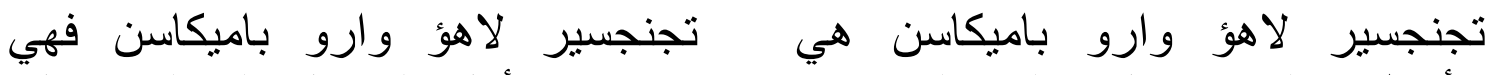

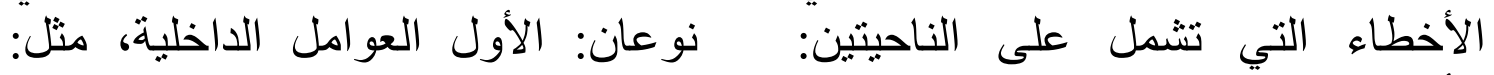

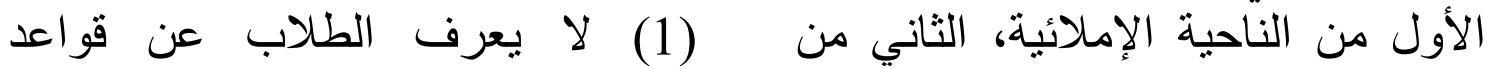

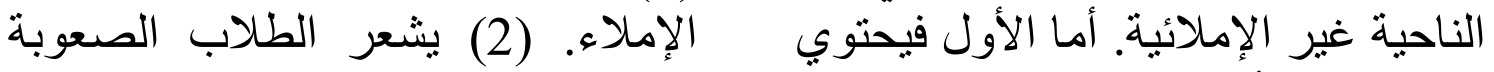

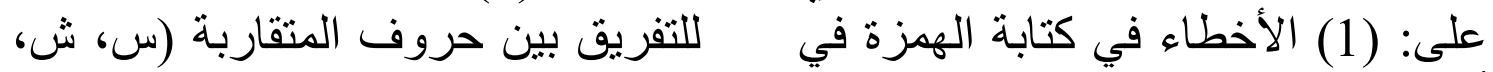

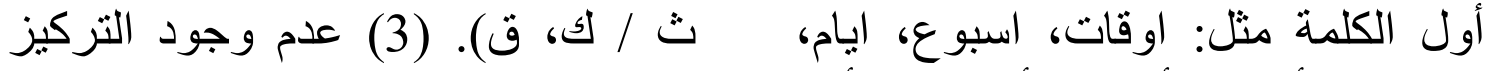

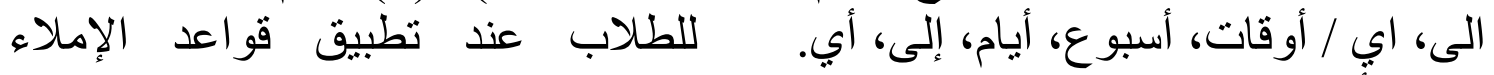

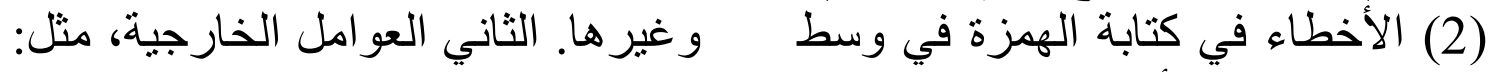

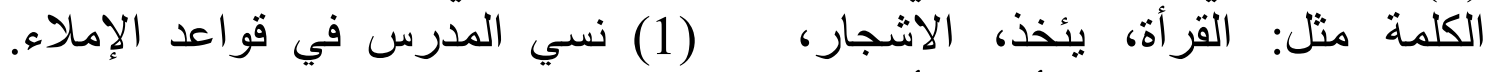

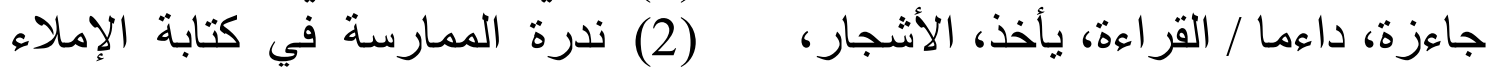

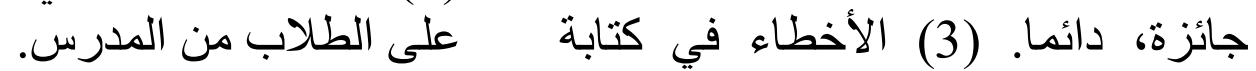

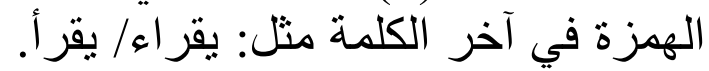

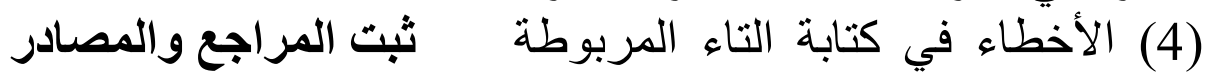

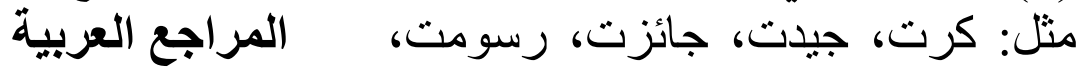

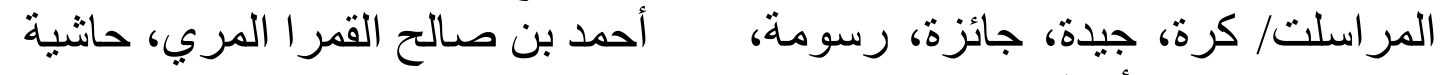

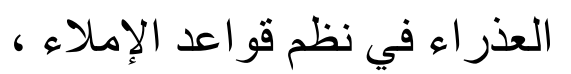

$$
2008
$$

حسين والي، كتاب الإملاء، (بيروت

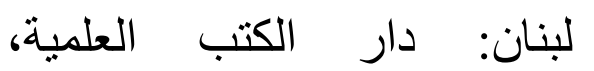

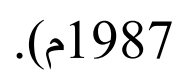

الدكتور عبد الحميد عبد الله وأصدقائه. أسس إعداد الكتب التعليمية لغير النيد الناطقين بالعربية، (القاهرة: دار

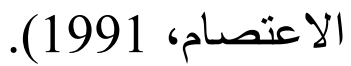

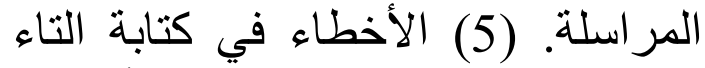
المفتوحة مثل: اوقاة، المجلاة/ أوقات، الأهاء

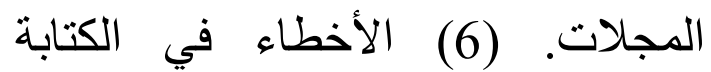

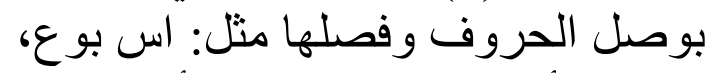

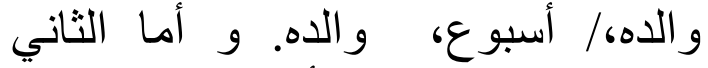
فيحتوي على: (1) الأخطاء في الكتابة

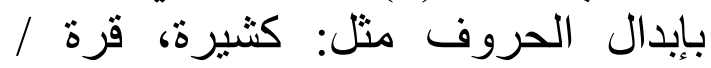
كثيرة، كرة. (2) الأخطاء في الني الكتابة بزيادة الحروف أو النبرة، مثل: كثير الاة، فئاء

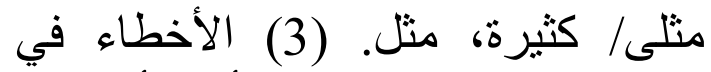
الكتابة بنقص الحروف الألف أو الياء

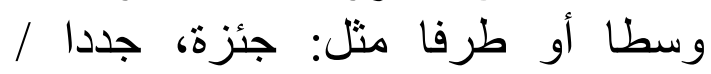
جائزة، جديدا. (4) الأخطاء في الكتابة 
Thabrani, Abdul Mukti., Kaidah-Kaidah Dasar Penulisan Bahasa Arab, (Pamekasan: Elmona Center, 2011).
الدكتور علي أحمد مذكور. تدريس فنون

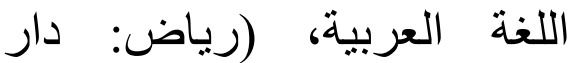
الثواف، (1991).

الدكتور حسن شحاتة. تعليم اللغة العربية بين النظرية و التطبيق، (القاهرة:

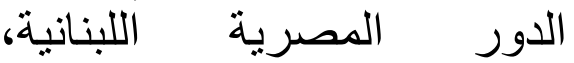
. (1994

رضوان. الإملاء نظريته و وتطبيقه،

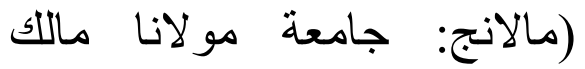
إبراهيم الإسلامية الحكومية،

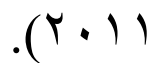

عبد العليم إبراهيم. الموجه الفني لمدرس اللغة العربية، (مصير:

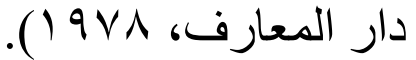
محمود رشدي خاطر وأصدقائه. طرق المرته تدريس اللغة العربية والتربية الدينية: في ضئ ضوء الاتجاهات التربوية الحديثة. (القاهرة: دار

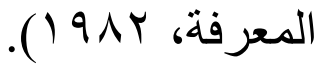

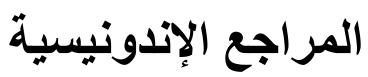

Ary, Donald., et.al, Introduction to Research in Education, (New York: Rinehart Winston 1979).

Parera, Jos Daniel., Linguistik Edukasional; Metodologi Pembelajaran Bahasa Analisis Kontrastif Antar Bahasa Analisis Kesalahan Berbahasa, (Jakarta: Erlangga, 1997).

Moleong, Lexy J., Metodologi Penelitian Kualitatif, (Bandung: PT. Remaja Rosdakarya, 2007).

Munjiah, Ma'rifatul., Imla' Teori \& Terapan, (Malang: UIN Malang, 2009). 